\title{
Lignin from Micro- to Nanosize: Applications
}

\author{
Stefan Beisl * (D), Anton Friedl and Angela Miltner \\ Institute of Chemical, Environmental and Biological Engineering, TU Wien, 1060 Vienna, Austria; \\ anton.friedl@tuwien.ac.at (A.F.); angela.miltner@tuwien.ac.at (A.M.) \\ * Correspondence: stefan.beisl@tuwien.ac.at; Tel.: +43-1-58801-166258
}

Received: 15 October 2017; Accepted: 6 November 2017; Published: 8 November 2017

\begin{abstract}
Micro- and nanosize lignin has recently gained interest due to improved properties compared to standard lignin available today. As the second most abundant biopolymer after cellulose, lignin is readily available but used for rather low-value applications. This review focuses on the application of micro- and nanostructured lignin in final products or processes that all show potential for high added value. The fields of application are ranging from improvement of mechanical properties of polymer nanocomposites, bactericidal and antioxidant properties and impregnations to hollow lignin drug carriers for hydrophobic and hydrophilic substances. Also, a carbonization of lignin nanostructures can lead to high-value applications such as use in supercapacitors for energy storage. The properties of the final product depend on the surface properties of the nanomaterial and, therefore, on factors like the lignin source, extraction method, and production/precipitation methods, as discussed in this review.
\end{abstract}

Keywords: lignin; nanoparticles; microparticles; biorefinery; reinforcing; antibacterial; UV-blocker; drug carrier; nanocomposites

\section{Introduction}

Lignocellulosic biomass residues are estimated to exceed $2 \times 10^{11} \mathrm{t} /$ year worldwide and offer a vast source for lignin [1]. Most of the lignin is currently used as an energy source. However, economic analysis has proved that the use of biomass for energy applications alone, in many cases, is not economically viable and utilization of the entire biomass through multiple processes is needed to improve the economics [2]. Only about $40 \%$ of the generated lignin is needed to cover the internal energy demand of a biorefinery [3,4]. Hence, $60 \%$ of the generated lignin is available to maximize valorization in addition to the valorization of the carbohydrate fractions.

Lignin in nanoscale can be one of the keys to maximize valorization of the input feedstock in a biorefinery, and "you can make anything you want out of lignin ... except money" [5] is changing to "Yes, we can make money out of lignin" [6]. For example, lignin-derived carbon nanofibers were successfully produced in pilot scale at Scion and Revolution Fibres (Auckland, New Zealand) and offer low production cost relative to other carbon nanomaterials [6].

Lignin is a highly irregularly branched polyphenolic polyether, consisting of the primary monolignols, p-coumaryl alcohol, coniferyl alcohol and sinapyl alcohol, which are connected via aromatic and aliphatic ether bonds [7] as well as non-aromatic $\mathrm{C}-\mathrm{C}$ bonds. The high complexity and inhomogeneity of the lignin structure is, in many cases, even further increased by currently applied pretreatment technologies and adds additional challenges for lignin's downstream processing and valorization [8,9]. Lignins can be roughly distinguished by their origin plant species and the processing method. In case of origin, three major types of lignin can be distinguished; where softwood lignins are comprised almost solely of coniferyl alcohol; hardwood lignins of both coniferyl and sinapyl alcohol; and grass lignins of all three types [10]. In the case of the processing method, two different routes can be identified: (1) lignin recovery before carbohydrate conversion; and (2) lignin recovery after 
carbohydrate conversion [11]. The latter is expected to be used for low-value markets, whereas lignin removal before fermentation through methods such as organosolv pretreatment or the use of ionic liquids as extraction solvent can result in lignin with little structural changes [11].

A possibility for overcoming the issue of high complexity and inhomogeneity is the use of the lignin at submicron scale, since nanostructured materials can have considerably different properties from larger-dimensional material of the same composition [12]. Production methods for lignin from micro- to nanosize in the shape of particles, fibers, tubes and sheets from different lignin sources were comprehensively compared in a previous review by the authors [13]. However, the lignin materials produced are, in most cases, only intermediates and need to be converted or applied in a final product or process. A summary of applications reported in recent literature is given in the present review.

\section{Application Overview for Lignin from Micro- to Nanosize}

A wide range of applications for lignin nanomaterials is reported in the literature. This review gives an overview of the present applications and their performance in the final product or process. Figure 1 gives a graphical overview of the published and potential applications.

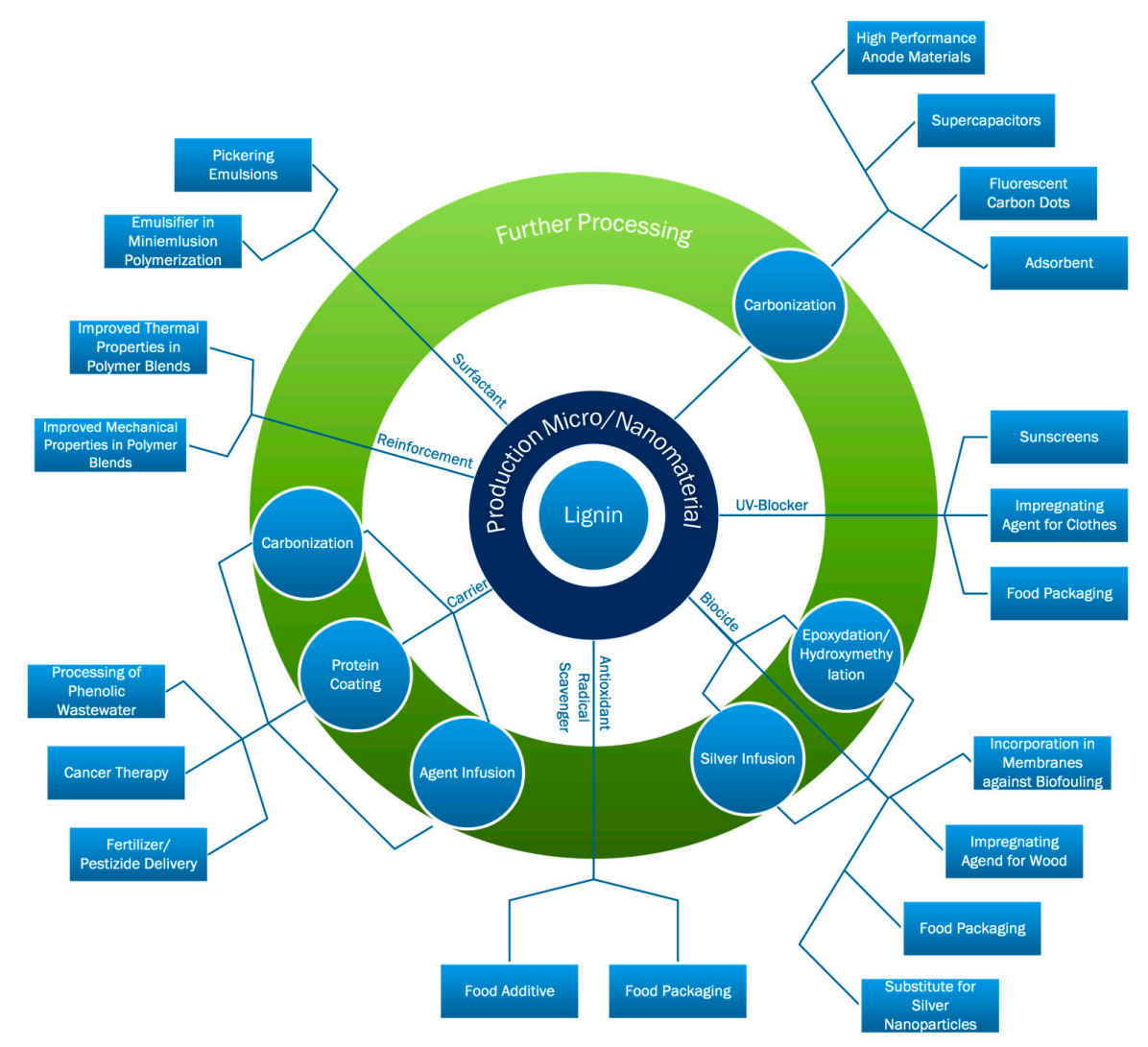

Figure 1. Overview of potential and investigated applications of lignin from micro- to nanosize published in literature.

Lignin shows many unique properties such as resistance to decay and biological attacks, ultraviolet (UV) absorption, high stiffness, and the ability to retard and inhibit oxidation reactions. Therefore, it offers the potential to produce high-value products from a large-volume feedstock $[14,15]$. Incorporation of nanoparticles in polymers can be a way to increase their values, since current properties can be improved and the materials can be provided with new features. This review is sectioned according to the fields of application of the materials. Therefore, the same polymer blends can be found in several chapters. Table 1 lists all polymer blends in order to give an overview of the fields of applications of polymer blends, the applied production methods, and properties. 
Table 1. Overview of investigated polymer blends.

\begin{tabular}{|c|c|c|c|c|}
\hline Investigated in & Neat Polymer & Production Method & Application Field and Neat Properties & $\begin{array}{l}\text { Investigated Properties by Addition of } \\
\text { Lignin Nanoparticles (LNPs) }\end{array}$ \\
\hline$[16,17]$ & Polylactic acid (PLA) & $\begin{array}{ll}- & \text { Extrusion } \\
- & \text { Solvent casting }\end{array}$ & $\begin{array}{l}\text { - Widely used as a packaging material } \\
\text { - } \\
\text { Poor thermal and mechanical properties; poor ultraviolet } \\
\text { (UV) barrier properties [18] }\end{array}$ & $\begin{array}{ll}- & \text { UV-transmittance } \\
- & \text { Antibacterial activity } \\
\text { - } & \text { Mechanical properties } \\
\text { - } & \text { Thermal properties }\end{array}$ \\
\hline [19] & Wheat gluten (WG) & $\begin{array}{l}\text { - } \quad \text { Solvent casting as described by } \\
\text { Kayserilioglu et al. [20] } \\
\text { Addition of aqueous LNP suspension to } \\
\text { the casting solution }\end{array}$ & $\begin{array}{l}\text { - Can be easily processed into films; effective barrier } \\
\text { properties against carbon dioxide, oxygen and aroma } \\
\text { components, rapidly biodegradable [21-24] } \\
\text { Poor mechanical properties; strong water absorption in } \\
\text { humid environment }\end{array}$ & $\begin{array}{ll}\text { - } & \text { UV-transmittance } \\
\text { - } & \text { Mechanical properties } \\
\text { - } & \text { Thermal properties } \\
\text { - } & \text { Water sensitivity }\end{array}$ \\
\hline [25] & Phenolic foams & $\begin{array}{l}\text { - Mixing dry lignin particles with } \\
\text { resol resin } \\
\text { Mixing of resol resin, surfactant, catalyst, } \\
\text { hardener and blowing agent }\end{array}$ & $\begin{array}{l}\text { - } \quad \text { Low thermal conductivity; exceptional fire-resistant } \\
\text { properties; high thermal stability; low cost }[26] \\
\text { Relatively low mechanical performance; extreme friability } \\
\text { compared to other polymeric foams }[27,28]\end{array}$ & - $\quad$ Mechanical properties \\
\hline [29] & Cellulose triacetate (CTA) & $\begin{array}{ll}\text { - } & \text { Solvent casting } \\
\text { - } & \text { Separate solving of CTA and LNPs } \\
\text { in methylenchloride }\end{array}$ & $\begin{array}{ll}\text { - } & \text { Membrane production } \\
\text { - } & \text { Low mechanical strength; poor resistance to oxidation [30] }\end{array}$ & - $\quad$ Mechanical properties \\
\hline [31] & $\begin{array}{l}\text { Glycidyl methacrylate } \\
\text { grafted PLA }\end{array}$ & - $\quad$ Extrusion & $\begin{array}{l}\text { - Widely used as a packaging material } \\
\text { - } \quad \text { Poor thermal and mechanical properties; poor UV barrier } \\
\text { properties [18] }\end{array}$ & $\begin{array}{ll}- & \text { UV-transmittance } \\
\text { - } & \text { UV-weathering stability } \\
\text { - } & \text { Mechanical properties } \\
\text { - } & \text { Thermal properties }\end{array}$ \\
\hline$[32,33]$ & $\begin{array}{l}\text { Poly vinyl alcohol } \\
\text { (PVA)/chitosan }(\mathrm{CH})\end{array}$ & Solvent casting & $\begin{array}{l}\text { - Widely used in food packaging, biomedical, household and } \\
\text { construction sector } \\
\text { - Good solvent resistance, mechanical performance und } \\
\text { biocompatibility [34,35] } \\
\text { - High moisture absorption; low biodegradation rate }\end{array}$ & $\begin{array}{ll}- & \text { UV-transmittance } \\
- & \text { Thermal properties } \\
- & \text { Mechanical properties } \\
- & \text { Migration } \\
- & \text { Antioxidant activity } \\
\text { - } & \text { Antibacterial activity }\end{array}$ \\
\hline [36] & $\begin{array}{l}\text { Bio-poly (trimethylene } \\
\text { terephthalate) }\end{array}$ & - $\quad$ Extrusion & $\begin{array}{l}\text { - Good tensile behavior, outstanding elastic recovery and } \\
\text { thermal stability [37] }\end{array}$ & $\begin{array}{ll}\text { - } & \text { Thermal properties } \\
\text { - } & \text { Mechanical properties } \\
\text { - } & \text { Biodegradation }\end{array}$ \\
\hline
\end{tabular}




\section{Application of Lignin Nanoparticles (LNPs) as Reinforcement}

Nanofillers can improve mechanical properties like stiffness, strength and toughness as well as thermal stability and barrier properties [38]. Those nanocomposites can perform better in comparison to traditional composites due to the higher specific surface of the nanofillers [39]. This section focuses mainly on the mechanical properties, where other properties are discussed in different sections.

Del Saz-Orozco et al. [25] used softwood calcium lignosulfonate particles with an average diameter of $1.6 \mu \mathrm{m}$ to reinforce phenolic foams. The incorporation of $8.5 \mathrm{wt} \%$ of lignin particles in the foam resulted in the greatest mechanical performance and makes it in those terms competitive with synthetic fiber-reinforced phenolic foams. The addition of lignin particles showed a compressive modulus and strength of $128 \%$ and $174 \%$, respectively, compared to the neat phenolic foam.

Nevárez et al. [29] incorporated lignin nanoparticles (LNPs) in cellulose triacetate (CAT) membranes and studied the impacts of organosolv lignin (OS), hydrolytic lignin and Kraft lignin $(\mathrm{KL})$ in acetylated and non-acetylated form on the mechanical properties. With only a few exceptions, the mechanical properties were considerably improved through the incorporation of $1 \mathrm{wt} \%$ lignin. The hydrolytic lignin, showing the smallest particle sizes among the studied lignins, resulted in the highest Young's moduli. The membranes can be applied in water purification and might reduce biofouling.

Tensile properties, like the tensile strength $(\sigma)$, modulus $(E)$, and elongation at break $\left(\varepsilon_{b}\right)$, are very important indicators for the selection of diverse applications for polymeric formulations [40]. Table 2 shows these parameters for various polymers and their counterpart with incorporated LNPs. The given data shows that the incorporation of LNPs in the right concentration leads to an improved mechanical behavior in all cases.

Table 2. Mechanical properties of different neat polymers in comparison to their nanocomposites.

\begin{tabular}{|c|c|c|c|c|c|}
\hline Source & Polymer & $\begin{array}{l}\text { Filler Composition and } \\
\text { Concentration }\end{array}$ & $\begin{array}{c}\text { Tensile Strength } \sigma \\
\text { (MPa) }\end{array}$ & $\begin{array}{c}\text { Young's Modulus } \\
E(\mathrm{MPa})\end{array}$ & $\begin{array}{l}\text { Elongation at } \\
\text { Break } \varepsilon_{b}(\%)\end{array}$ \\
\hline \multirow{2}{*}{ [19] } & \multirow{2}{*}{ Wheat gluten } & neat & $5.5 \pm 0.8$ & $180.5 \pm 57.9$ & $297 \pm 11$ \\
\hline & & $3 \mathrm{wt} \% \mathrm{LNP}$ & $13.3 \pm 1.6$ & $553.2 \pm 56.3$ & $28 \pm 10$ \\
\hline \multirow{2}{*}{ [32] } & \multirow{2}{*}{ PVA } & neat & $45.7 \pm 1.3$ & $1140 \pm 220$ & $164 \pm 15$ \\
\hline & & $3 \mathrm{wt} \% \mathrm{LNP}$ & $51.4 \pm 3.3$ & $2100 \pm 130$ & $30.6 \pm 8.5$ \\
\hline \multirow{3}{*}{ [17] } & \multirow{3}{*}{ PLA } & neat & $44.0 \pm 4.6$ & $2010 \pm 210$ & 15.0 \\
\hline & & $3 \mathrm{wt} \% \mathrm{LNP}$ & $41.1 \pm 1.9$ & $1390 \pm 60$ & 66.3 \\
\hline & & 1 wt $\%$ LNP + 3 wt $\%$ CNC & $53.6 \pm 6.9$ & $2500 \pm 170$ & 7.3 \\
\hline \multirow{4}{*}{ [31] } & \multirow{4}{*}{ PLA/g-PLA } & neat PLA & $44.4 \pm 4.3$ & $1950 \pm 250$ & $16.9 \pm 4.0$ \\
\hline & & PLA + $1 w t \%$ LNP & $48.6 \pm 3.5$ & $2150 \pm 130$ & $26.8 \pm 4.8$ \\
\hline & & g-PLA+ 1 wt $\%$ LNP & $47.2 \pm 3.1$ & $1630 \pm 110$ & $108 \pm 20$ \\
\hline & & PLA/g-PLA + 1 wt \% LNP & $56.4 \pm 3.3$ & $2120 \pm 140$ & $20.4 \pm 8.9$ \\
\hline \multirow{3}{*}{ [16] } & \multirow{3}{*}{ PLA } & neat & $44.3 \pm 4.6$ & $1960 \pm 230$ & $17.0 \pm 3.8$ \\
\hline & & PLA + 1 wt \% LNP & $48.6 \pm 3.4$ & $2150 \pm 130$ & $26.7 \pm 4.8$ \\
\hline & & PLA + 3 wt \% LNP & $40.9 \pm 2.1$ & $1380 \pm 60$ & $66.7 \pm 4.0$ \\
\hline \multirow{2}{*}{ [41] } & \multirow{2}{*}{ Natural rubber } & neat & $25.24 \pm 0.38$ & $2.00 \pm 0.03^{2}$ & $654 \pm 13$ \\
\hline & & 7 wt $\%$ LNP 1 & $29.24 \pm 0.59$ & $2.95 \pm 0.10^{2}$ & $658 \pm 20$ \\
\hline \multirow{3}{*}{ [36] } & \multirow{3}{*}{ bio-PTT } & neat & $51.49 \pm 0.5$ & $2058 \pm 37$ & - \\
\hline & & $1.5 \mathrm{wt} \% \mathrm{LNP}$ & $59.16 \pm 0.7$ & $2227 \pm 47$ & - \\
\hline & & $\begin{array}{c}1.5 w t \% \text { LNP }+7 w t \% \\
\text { carbon fibers }\end{array}$ & $61.74 \pm 0.6$ & $2309 \pm 9$ & - \\
\hline
\end{tabular}

${ }^{1}$ Based on the weight of lignin in the particles; ${ }^{2}$ at $300 \%$ elongation not at break.

\section{Applications of Lignin Nanoparticles as Ultraviolet (UV) Blocker}

Lignin contains UV-absorbing functional groups such as phenolic, ketone and other chromophores [42,43]. This UV-absorbing property can be used in applications like suncreens or the impregnation of textiles. The effectiveness of this property can even be improved if the lignin is used at nanoscale. Yearla and Padmasree [44] tested the protection of Escherichia coli against UV 
irradiation by hardwood dioxane lignin and softwood alkali lignin and their complementary nano version, respectively. The UV protectant activity of the nanolignin showed up to a $30 \%$ increase in comparison to the non-nanolignin. The UV-absorption spectra of KL nanospheres in an aqueous environment were compared to non-nano KL by Li et al. [45]. The nanospheres with an average hydrodynamic radius of $145 \mathrm{~nm}$ showed quite different absorption characteristics compared to the non-nano KL despite their identical chemical composition. Both samples show an absorption maximum at $283 \mathrm{~nm}$, but the nanospherical KL exhibits a broader absorption band in the longer wavelength region and also shows a shoulder towards the longer wavelength region.

Zimniewska et al. [46] treated linen and hemp fabric as well as non-woven flax with nanostructured KL obtained by sonication. The treatment gives the textiles excellent UV-protection while not worsening their physical and bio-physical properties. Using a silicone emulsion for a better fixation of the nanoparticles improved the UV-protection by almost 5 times in comparison with non-treated linen fabric.

Qian et al. [47,48] used lignin from different sources to successfully produce sunscreens. Hydrophobic lignin showed the best performance blended in pure NIVEA ${ }^{\mathrm{TM}}$ cream, but the synergetic effect with commercial sunscreens must be emphasized. The addition of $10 \mathrm{wt} \%$ OS to a commercial sunscreen increased the sun protection factor (SPF) values from 15 to 91.61 and improved its photo stability. In their most recent work, different spherical sizes of the incorporated lignin were investigated, including lignin in nanoscale [49]. It was found that the SPF value of the sunscreens increases with decreasing size of lignin colloidal spheres. While usually, commercial sunscreens need at least $20 \mathrm{wt} \%$ chemical sunscreen actives to reach SPF 15, sunscreen containing $10 \mathrm{wt} \%$ OS colloidal spheres with the size of about $50 \mathrm{~nm}$ reaches the identical SPF value.

Yang et al. $[17,19,31,32]$ incorporated LNPs and cellulose nanocrystals (CNC) in wheat gluten (WG), polyvinyl alcohol (PVA), chitosan (CH), glycidyl methacrylate grafted polylactic acid (g-PLA) and neat polylactic acid (PLA). The UV- and visible light-blocking properties of selected blends can be seen on the UV-Vis spectra in Figure 2. Wheat gluten films with incorporated LNPs $(0 \mathrm{wt} \%$, $1 \mathrm{wt} \%$ and $3 \mathrm{wt} \%$ ) were prepared with a casting method described by Kayserilioglu et al. [20] and aqueous LNP dispersion was added to the casting solution under vigorous stirring. Incorporation of LNPs decreases the light transmittance in the visible light spectrum indicated by the transmittance at a wavelength of $550 \mathrm{~nm}$, which decreases from $89 \%$ for neat WG to $56 \%$ for WG containing $3 \mathrm{wt} \%$ LNPs. In the UV range (below $400 \mathrm{~nm}$ ) of the spectra, transmittance below $2 \%$ were reached for the LNP containing PVA and WG samples [19]. Binary and ternary polymer films with PVA, CH and LNPs were prepared via solvent casting, and the UV transmittance was reduced from $90.79 \%$ to $0.39 \%$ for PVA containing $3 \mathrm{wt} \%$ LNPs at a wavelength of $320 \mathrm{~nm}$. Ternary mixtures reached transmittance values of $0.87 \%$ at $320 \mathrm{~nm}$ [32]. PLA films were also produced by extrusion and contained neat PLA, g-PLA and LNPs. The blend consisting of g-PLA and 1 wt \% LNPs blocks about $28 \%$ of the UV-B (280-315 nm) irradiation [31]. A synergetic effect of incorporated LNPs and CNCs in PLA films was found with respect to their transparency and UV-light blocking capability. Two different amounts of cellulose nanocrystals and lignin nanoparticles were incorporated in a PLA and g-PLA matrix via melt extrusion. The transmittance at a wavelength of $320 \mathrm{~nm}$ could be decreased from $91.4 \%$ for neat PLA, to $57.8 \%$ for PLA with $3 \mathrm{wt} \%$ LNP and to $46.2 \%$ for PLA including $3 \mathrm{wt} \%$ LNP and $3 \mathrm{wt} \%$ CNC [17]. 


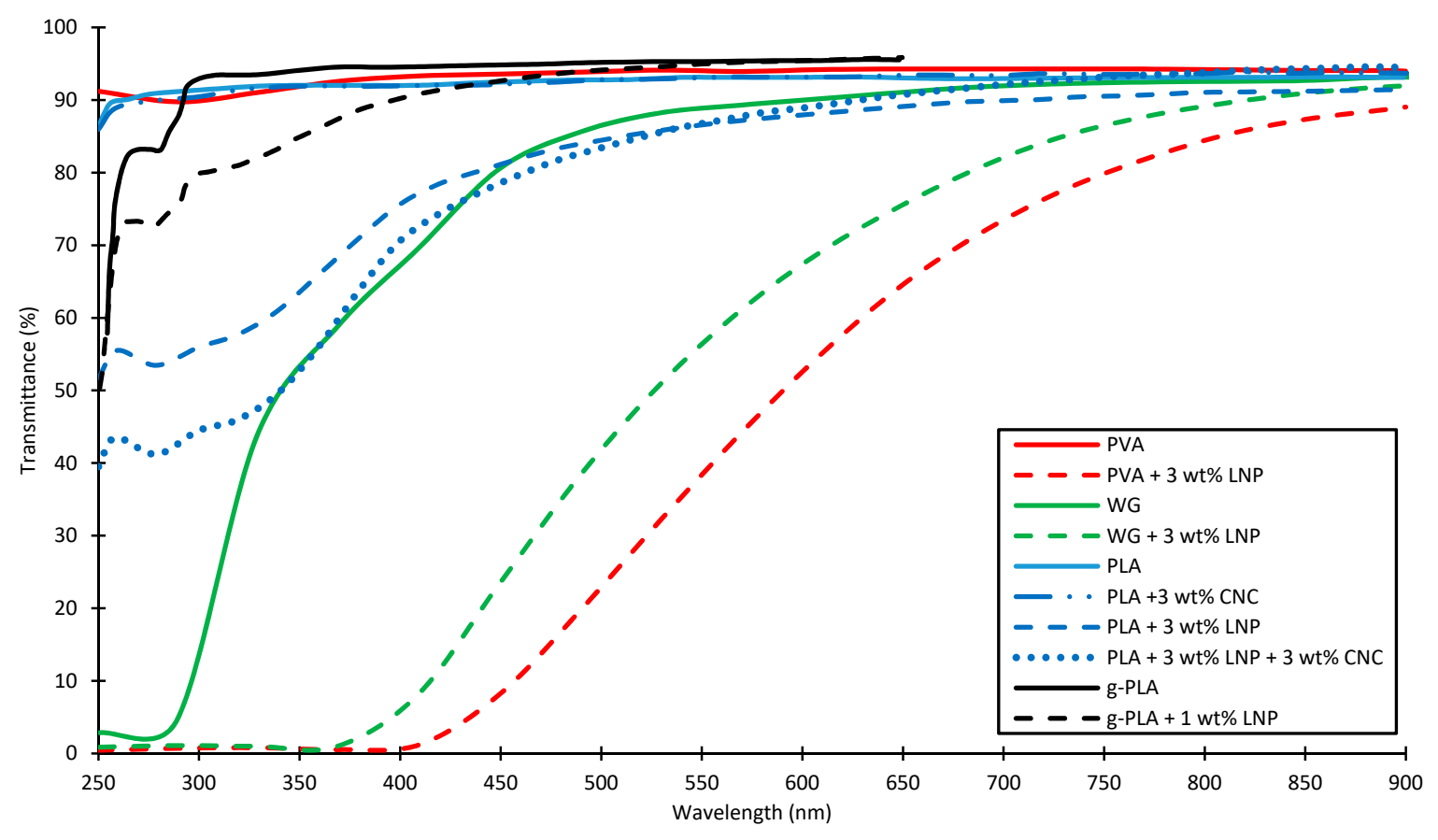

Figure 2. UV-Vis transmission spectra of Polyvinyl alcohol (PVA), Wheat gluten (WG) and Polylactic acid (PLA) polymer blend films with incorporated lignin nanoparticles (LNPs) and cellulose nanocrystals (CNCs). Adapted from [17,19,31,32], with permission from Elsevier.

\section{Application of Lignin Nanoparticles as Biocide}

Lignin contains different phenolic monomer fragments and is an important source of natural antibacterial compounds. Phenolic fragments containing a double bond in $\alpha, \beta$ positions of the side chain and a methyl group in the $\gamma$ position show, in general, the most inhibitory effect [50]. Lignin from different sources, different extraction methods and even a series of lignin model compounds showed successful antimicrobial properties against various microorganisms [51-53]. The polyphenolic compounds of lignin cause cell membrane damage and lysis of bacteria with subsequent release of cell content $[50,54]$. Nanoparticles offer a huge surface area and, therefore, more functional and polyphenolic sidechains on their surface. This increases the contact area and can increase the antimicrobial effect.

Silver nanoparticles, on the other hand, also show effective antimicrobial, antifungal and antiviral properties $[55,56]$. However, recovery or deactivation of those particles in incineration or wastewater after their intended use is arduous and may adversely affect many ecosystems [57-60].

Popa et al. [61] and Gîlcă et al. [62] investigated epoxidated and hydroxymethylated lignin nanoparticles as an impregnating agent for wood. Oak, birch and poplar veneer samples were treated with nanoparticle dispersions, buried in garden soil sown with wheat for 6 months and evaluated by their mass loss and variation of contact angle. The birch veneer sample treated with a combination of $\mathrm{CuCl}$ and hydroxmethylated sarkanda grass alkali LNPs showed the best results in terms of mass loss. The reference sample showed a mass loss of $80 \mathrm{wt} \%$ whereas the treated sample only showed $8.7 \mathrm{wt} \%$ [61]. Epoxylated LNPs from commercial Protobind 1000, 2000 and 3000 with average particle diameters of 70-200 nm without addition of $\mathrm{CuCl}$ were used for the impregnation of poplar and oak veneer. The mass loss of the untreated reference samples was $37 \mathrm{wt} \%$ and $40.1 \mathrm{wt} \%$ for poplar and oak, respectively. The best results for oak were achieved by treatment with Protobind 1000 LNPs and a reduction of the mass loss to $20.5 \mathrm{wt} \%$, whereas Protobind 3000 LNPs showed the best result for poplar and reduced mass loss to $9.5 \mathrm{wt} \%$ [62]. Those results show improved wood resistance to biodegradation. However, tailored formulations for each wood type seem to be necessary. 
Zimniewska et al. [46] impregnated linen fabric with LNPs from Kraft Lignin and achieved antibacterial activity for eight bacteria cultures which are most often found in human environments.

The antibacterial activity of LNPs incorporated in polymer films for food packaging was evaluated by Yang et al. [17,32]. A liquid medium test [63] was used in all experiments. Two different PLA blends, one containing $3 \mathrm{wt} \% \mathrm{LNPs}$ and one containing $3 \mathrm{wt} \% \mathrm{LNPs}$ and $1 \mathrm{wt} \% \mathrm{CNCs}$, and neat PLA were tested against the bacterial plant pathogen Pseudomonas syringae pv. tomato (Pst). This bacterium affects tomatoes production worldwide causing serious damage to all organs, including fruits that result unmarketable [64]. In the other study, the biocidal activity of neat PVA, $\mathrm{CH}, \mathrm{PVA} / \mathrm{CH}$ films and nanocomposites containing LNPs was evaluated against Xanthomonas arboricola pv. pruni (CFBP 3894) and Pectobacterium carotovorum subsp. odoriferum (CFBP 1115) bacterial plant pathogens [32]. Both bacteria can damage fresh fruits and vegetables in open fields and after harvesting [32,65]. The results of investigation can be seen in Figure 3. All LNP-incorporated polymer blends showed lower colony-forming unit (CFU) concentrations within the first $3 \mathrm{~h}$ of immersion in the nutrient broth. After $24 \mathrm{~h}$, the Xanthomonas arboricola pv. Pruni and Pseudomonas syringae pv. tomato concentrations in the tests with incorporated LNPs were significantly lower compared to the neat polymers. However, increasing CFU concentrations were observed in each sample between $3 \mathrm{~h}$ and $24 \mathrm{~h}$ but remained at lower CFU concentrations compared to the neat polymers [17,32].
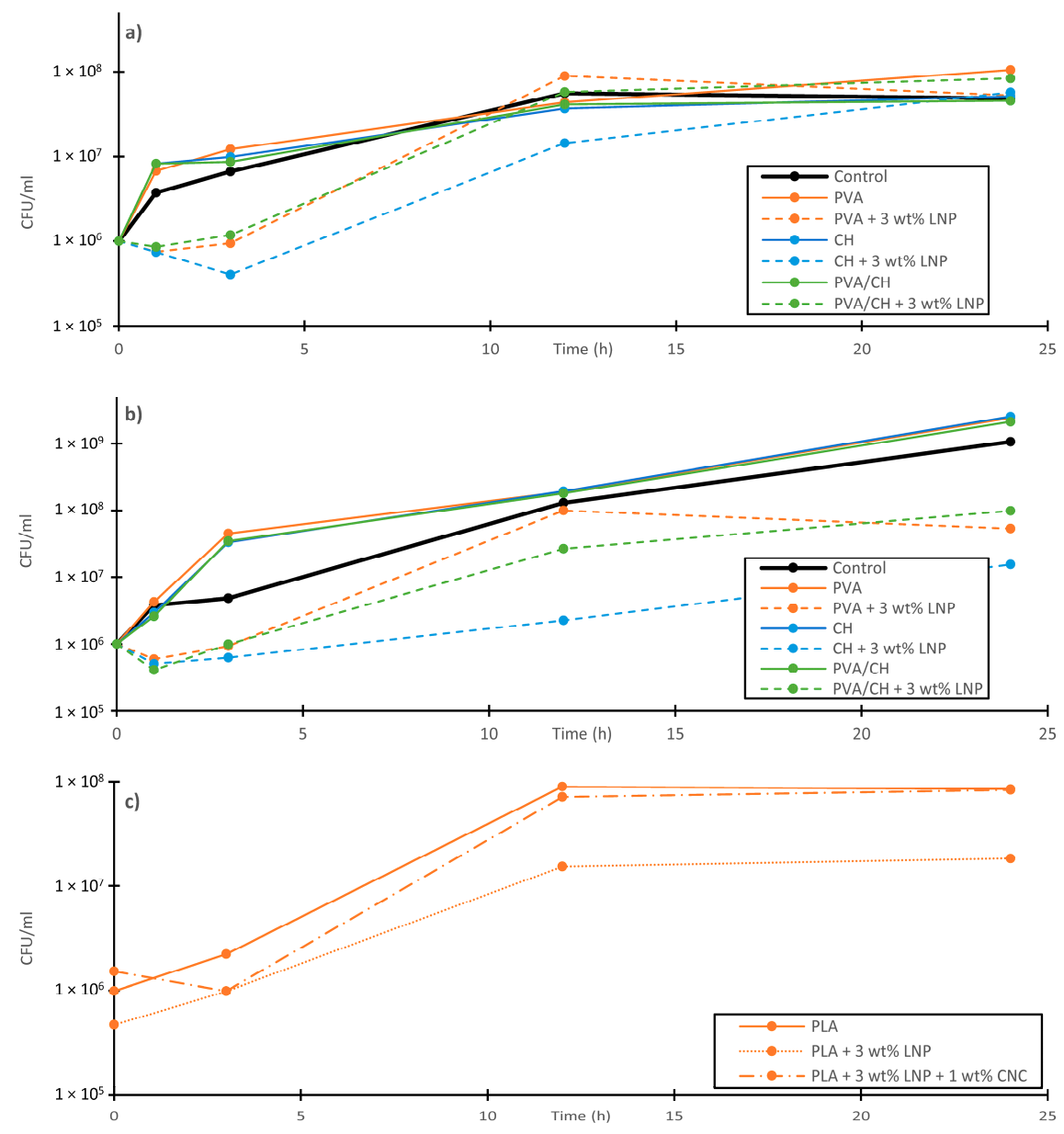

Figure 3. Results of the antimicrobial liquid medium test of polylactic acid (PLA), polyvinyl alcohol (PVA) and chitosan (CH) polymer blends against different bacteria; (a) Pectobacterium carotovorum subsp. odoriferum (CFBP 1115); (b) Xanthomonas arboricola pv. pruni (CFBP 3894); (c) Pseudomonas syringae pv. tomato (CFBP 1323). Adapted from Yang et al. [17,32], with permission from Elsevier. 
Richter et al. [66] combined the strong antimicrobial properties of silver with the biodegradability of lignin. Indulin $\mathrm{AT}^{\mathrm{TM}}$ lignin, obtained by a Kraft pulping process, was used to obtain an environmentally benign core in nanosize. The nanoparticles were precipitated via $\mathrm{pH}$ shift and had a mean hydrodynamic diameter of $84 \pm 5 \mathrm{~nm}$ [67]. Afterwards, particles were infused with $\mathrm{Ag}^{+}$ions in an aqueous solution of $\mathrm{AgNO}_{3}$ and coated with polydiallyldimethylammonium chloride (PDAC) to shift the zeta potential of the particles to positive values. Those silver infused particles are capable of neutralizing common Gram-negative and Gram-positive human pathogens as well as quaternary amine-resistant bacteria. The amount of silver used was 10 times less in comparison to conventional silver nanoparticles and aqueous $\mathrm{AgNO}_{3}$ solution. Figure 4 shows the proposed schematics of bactericidal activity and behavior of the particles after release into the environment. Both particles release $\mathrm{Ag}^{+}$ions which cause the bacteria to die. The silver-infused lignin particle is supposed to not contain $\mathrm{Ag}^{+}$ions after utilization and remain as a biodegradable lignin particle, whereas the silver nanoparticle still releases $\mathrm{Ag}^{+}$ions after utilization.

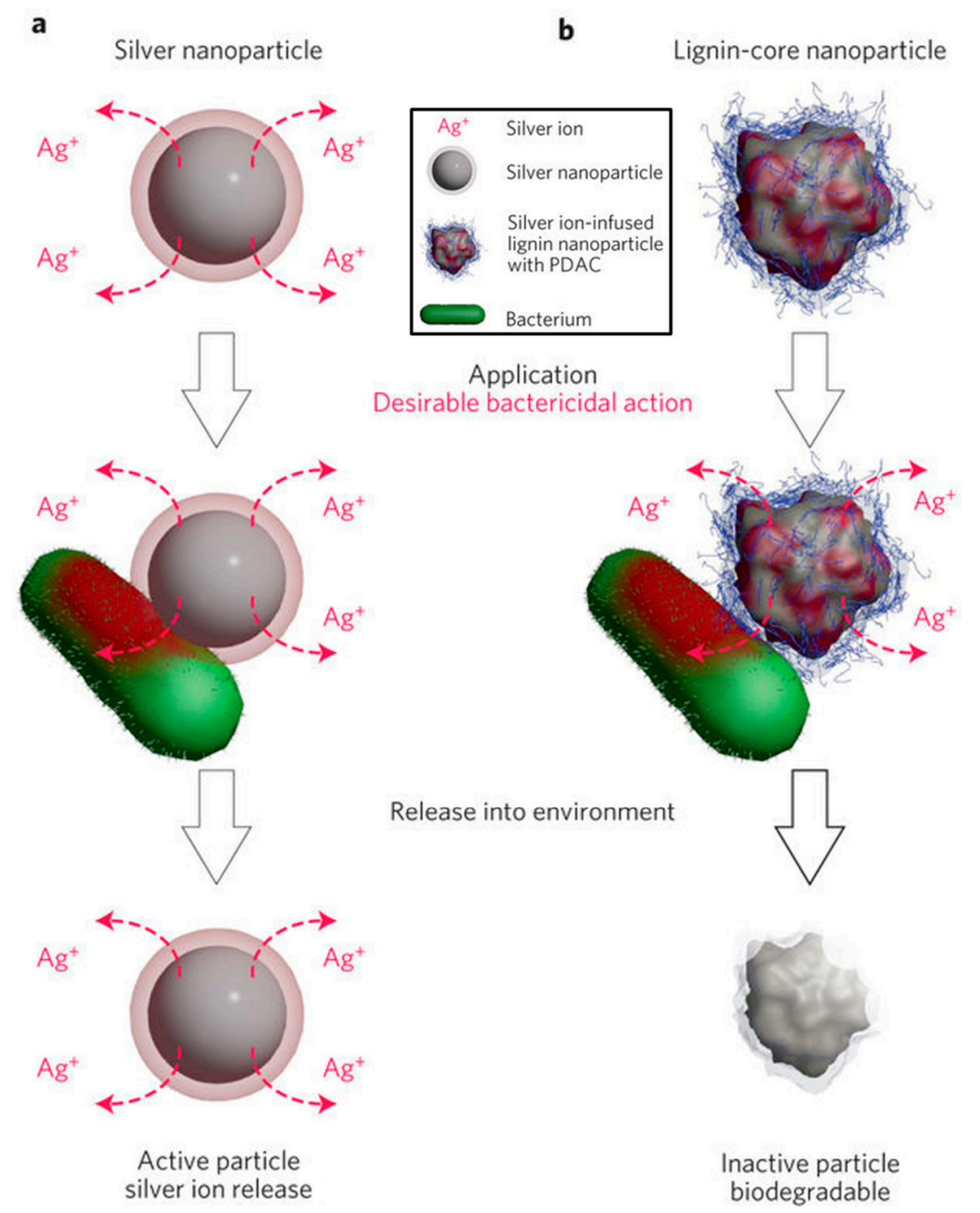

Figure 4. Proposed use cycle and principle of the bactericidal action of environmentally benign lignin-core nanoparticles (b) and the currently used silver nanoparticles (a). Reprinted by permission from Macmillan Publishers Ltd.: Nature Nanotechnology [66], Copyright 2015. 


\section{Applications of Lignin Nanoparticles as Antioxidants/Radical Scavengers}

Lignin is an effective free-radical scavenger, which can reduce oxygen radicals, and retard and inhibit oxidation reactions [68,69]. Most antioxidant effects of lignins are considered as derived from the scavenging action of their phenolic structures on oxygen-containing reactive free radicals. Therefore, the reducing power of a compound may serve as a significant indicator of the potential antioxidant activity [70]. The scavenging activity is predominantly based on non-etherified phenolic hydroxyl groups, ortho-methoxy groups and aliphatic hydroxyl groups in the side chain [69].

Lu et al. [71] compared the 2,2-diphenyl-1-picrylhydrazyl (DPPH) radical-scavenging activity (RSA), reducing power, superoxide radical-scavenging activity (SRSA) and water solubility of nanoscale poplar OS $(144 \pm 30 \mathrm{~nm})$ in comparison with non-nanoscale lignin. The chemical of structure of nanoscale lignin did not change compared to the non-nanoscale lignin. The results in Figure 5 show improved RSA, reducing power and SRSA for the LNPs in comparison to the non-nanoscale lignin. Surprisingly, the solubility increased more than 12 -fold despite the same chemical composition. Further improvement of the RSA is possible by adaptation of the lignin extraction parameters, as indicated by Pan et al. [72] where ethanol OS from hybrid poplar with more phenolic hydroxyl groups, less aliphatic hydroxyl groups, low molecular weight, and narrow polydispersity showed high antioxidant activity. These properties were improved at elevated temperature, longer reaction time, increased catalyst concentration, and low ethanol/water ratio in the pretreatment process.
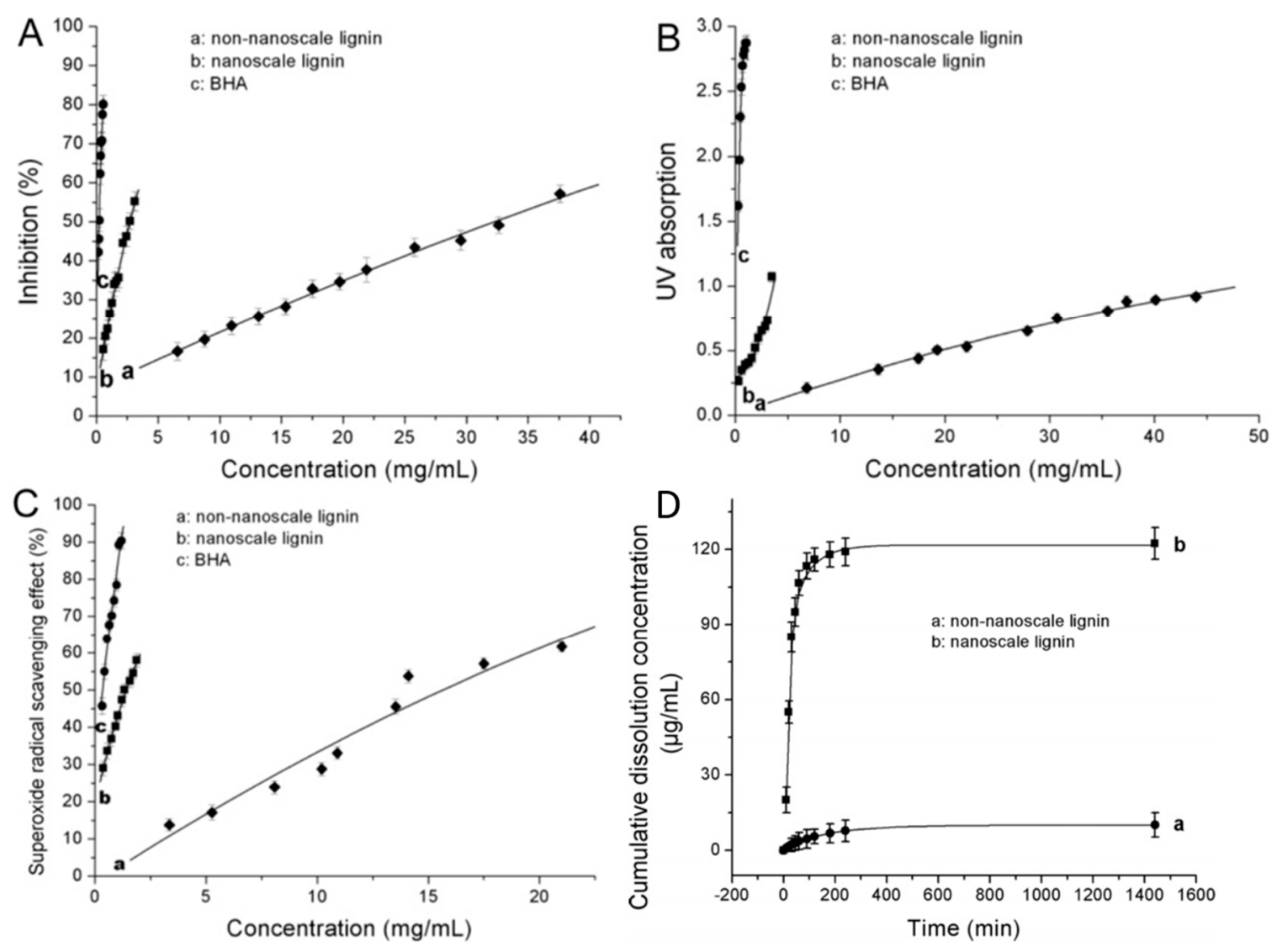

Figure 5. (A) 2,2-diphenyl-1-picrylhydrazyl (DPPH) radical-scavenging capacity; (B) reducing power; (C) superoxide radical scavenging activity; and (D) Dissolution profiles in water at room temperature of non-nanoscale lignin and nanoscale lignin. The antioxidant butylated hydroxyanisole (BHA) was used as control. Reprinted from [71], with permission from Elsevier. 
The improvement of RSA depending on the particle size of hardwood dioxane lignin and softwood alkali lignin was investigated by Yearla et al. [44]. The spherical LNPs had mean diameters ranging from $80 \mathrm{~nm}$ to $104 \mathrm{~nm}$. The RSA of the LNPs, however, showed only marginally differences when compared to their non-nanoscale lignins where the alkali lignin showed better performance compared to the dioxane lignin. These results are contrary to the findings of Lu et al. [71].

Ge et al. [73] investigated the free RSA of alkaline lignin LNPs produced by two different methods. The first using ethylene glycol as a solvent, and the second using alkaline water as shown in previous work for sugarcane bagasse [74]. The $\mathrm{IC}_{50}$ (dosage of lignin at free $\mathrm{RSA}=50 \%$ ) of each lignin was calculated, where a higher antioxidant activity is indicated by a lower $\mathrm{IC}_{50}$ value. The $\mathrm{IC}_{50}$ values are $0.18 \pm 0.01 \mathrm{mg} / \mathrm{mL}, 0.30 \pm 0.02 \mathrm{mg} / \mathrm{mL}$ and $0.60 \pm 0.05 \mathrm{mg} / \mathrm{mL}$ for LNPs precipitated by the second method, non-nanoscale lignin and LNPs precipitated by the first method, respectively. This indicates a dependency of the free RSA on the precipitation method of the LNPs.

Yang et al. [32] investigated the DPPH RSA for binary and ternary PVA/CH nanocomposites containing LNPs for active food packaging following the methods reported by Byun et al. [75] and Domenek et al. [76]. Neat PVA was used as control material. Nanocomposites containing $1 \mathrm{wt} \%$ LNPs reached a RSA of up to $78.2 \%$ and samples containing $3 \mathrm{wt} \%$ up to $92 \%$.

\section{Application of Lignin Nanoparticles as Surfactants in Pickering Emulsions}

Surfactants consist of polar head groups and nonpolar tails and are categorized by the chemistry of their headgroup, including anionic species based on fatty acids and sulfonate derivatives [77], cationic species based on arginine lipopeptides [78], and nonionic species based on alkyl polyglycosides [79]. Unlike traditional surfactant-stabilized emulsions, Pickering emulsions are stabilized by solid particles at the interface between the dispersed phase and the continuous phase [80]. The generally large energetic barrier associated with the particle desorption from the interface makes them inherently more stable against coalescence than their surfactant-based counterparts [81].

Nypelö et al. [82] stabilized hexadecane in water emulsions with KL particles with a size of about $320 \mathrm{~nm}$. The hexadecane droplets in the Pickering emulsion had average diameters of $7.7 \pm 1.6 \mu \mathrm{m}$ and $22.3 \pm 3.6 \mu \mathrm{m}$ for $0.6 \mathrm{wt} \%$ and $0.2 \mathrm{wt} \%$ particle concentrations, respectively. The emulsions were stable over the observation period of one week.

Wei et al. [83] used alkaline lignin as auxiliary material in the production of polystyrene (PS) microparticles (see Figure 6). Under acidic conditions at $\mathrm{pH} 4$, lignin forms particles with an average size of $182 \mathrm{~nm}$. These particles form a Pickering emulsion with the styrene/water. Styrene droplets are surrounded by the lignin particles and droplet size can be adjusted by the concentration of lignin particles. Droplet sizes from $22.31 \mu \mathrm{m}$ to $58.93 \mu \mathrm{m}$ were achieved for lignin concentrations based on water from $1 \mathrm{wt} \%$ to $0.05 \mathrm{wt} \%$. After polymerization of the styrene, lignin was recovered by raising the $\mathrm{pH}$ value and dissolving the lignin particles.

Nanoparticles grafted with surface active polymer chains can decrease surface and interfacial tensions and create stable Pickering emulsions [84-86]. Grafting properties like graft density, length and architecture can be controlled by techniques such as atom transfer radical polymerization (ATRP) [87], nitroxide-mediated radical polymerization (NMP) [88], and reversible addition-fragmentation chain transfer (RAFT) [89,90].

Table 3 shows the grafting methods and polymers used for the applications of grafted LNPs in Pickering emulsions. Gupta et al. [91] could form stable water-in-oil emulsions where the poly(acrylic acid) grafted LNPs performed significantly greater than polyacrylamide grafted ones regarding the partitioning into the emulsion phases. Emulsions were stable for weeks at room temperature. The solution viscosities did not increase significantly by adding grafted LNPs while the surface tensions decreased as a function of concentration, graft density, graft molecular weight and polymer chemistry. Silmore et al. [80] could produce Pickering emulsions stable for a period of months with only $0.1 \mathrm{wt} \%$ nanoparticle content. The interfacial tension was found to decrease with decreasing graft density and increasing salinity. 


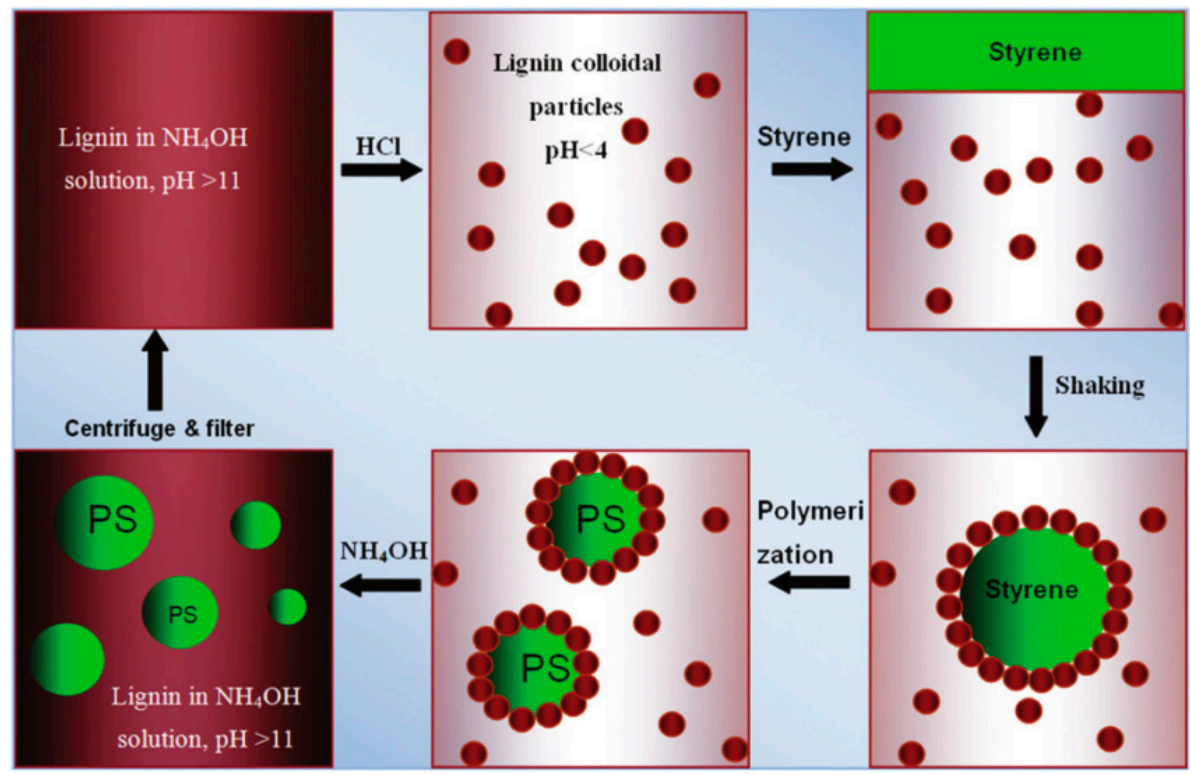

Figure 6. A schematic representation of the preparation of lignin-coated microparticles and bare polystyrene (PS) microparticles based on a lignin-stabilized Pickering emulsion including recirculation of lignin. Reproduced from [83] with permission of The Royal Society of Chemistry.

Table 3. Overview of the grafted LNPs for use in Pickering emulsions.

\begin{tabular}{ccccc}
\hline Source & Lignin Type & Grafting Method & Grafted Polymers & Stabilized Emulsion \\
\hline$[91]$ & KL & RAFT & $\begin{array}{c}\text { polyacrylamide } \\
\text { poly(acrylic acid) }\end{array}$ & water $/$ hexanes ${ }^{1}$ \\
\hline$[80]$ & KL & RAFT & polyacrylamide & water/cyclohexane \\
\hline$[92]$ & AL & ATRP & 2-(diethyl-amino)ethyl methacrylate & water/decane \\
\hline \multicolumn{5}{c}{${ }^{1}$ mixture of $\mathrm{C}_{6} \mathrm{H}_{14}$ isomers as well as methylcyclopentane. } \\
\end{tabular}

Qian et al. [92] developed a Pickering emulsion offering a gas-switchable feature. Figure 7 shows the highly reversible and repeatable process of dispersing decane in water by $\mathrm{CO}_{2}$ bubbling and precipitation by $\mathrm{N}_{2}$ bubbling. The dispersion and precipitation ability is determined by the grafting density and chain length of the 2-(diethyl-amino)ethyl methacrylate (DEAEMA) units where shorter chain length resulted in faster flocculation of the grafted lignin when switching to $\mathrm{N}_{2}$ bubbling. The diameters of the produced particles showed a range of 237-404 nm, and concentration of $1 \mathrm{~g} / \mathrm{L}$ grafted lignin based on the water content was sufficient to gain Pickering emulsions with a water-to-decane volumetric ratio of 4:1.

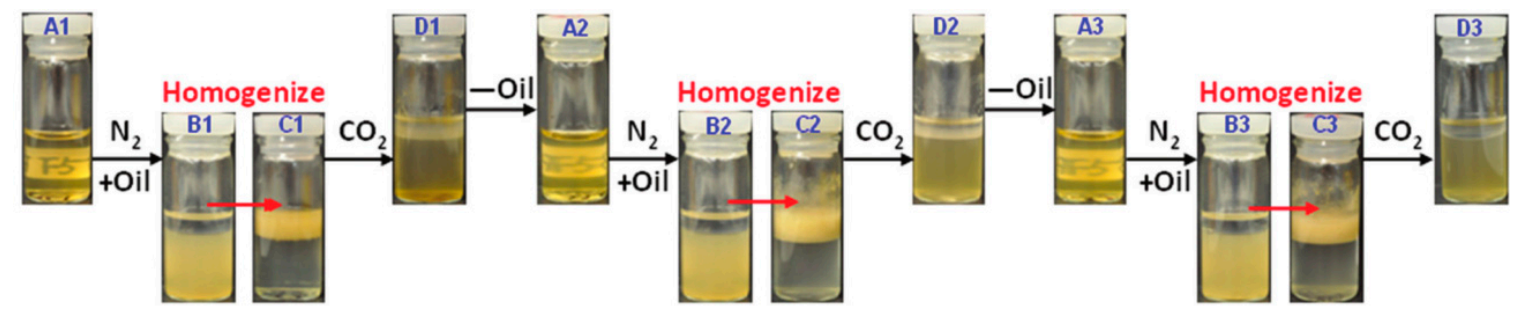

Figure 7. Illustration of three cycles of $\mathrm{CO}_{2}$-triggered emulsification and $\mathrm{N}_{2}$-triggered demulsification of lignin-g-DEAEMA water/decane Pickering emulsion. Reproduced from [92] with permission of The Royal Society of Chemistry. 


\section{Applications of Carbonized Lignin Nano Fibers and Particles}

Carbon nanostructures such as fibers and particles offer numerous possibilities for applications like batteries, supercapacitors, fuel cells, structural composites, filtration devices. Fluorescence carbon nanoparticles can be applied for biological labeling, bioimaging, and other optoelectronic device applications. Therefore, this topic is rapidly gaining interest in research [93-96]. Lignin can be used as a precursor for those carbon fibers and particles and opens application possibilities in high-value products. Carbon fibers from commercially available KL were already successfully produced by Kadla et al. [97] in 2002. Increasing tensile strength and modulus was observed with decreasing fiber diameter where the smallest diameters of about $30 \mu \mathrm{m}$ were achieved. This leads to the assumption that further reduction of diameters to nanoscale could significantly improve these properties.

$\mathrm{Hu}$ and Hsieh [98] produced highly porous activated carbon fibers by the electrospinning of aqueous solutions of predominantly spruce wood alkali lignin followed by simultaneous carbonization and activation at $850^{\circ} \mathrm{C}$ under an $\mathrm{N}_{2}$ atmosphere. These carbon fibers with diameters from 100 to $500 \mathrm{~nm}$ were fabricated into supercapacitors for capacitive energy storage and demonstrated outstanding electrochemical performance [99]. The capacitators reached an energy density of $8.1 \mathrm{Wh} / \mathrm{kg}$ based on the averaged electrode mass and over $96 \%$ capacitance-retention rates were achieved after 5000 charge/discharge cycles. Also, Lai et al. [100] used carbon nanofiber mats produced from electro-spun alkali lignin in high-performance supercapacitors. In this study, mixtures of alkali lignin/polyvinyl alcohol (PVA) were used and resulted after electrospinning in average fiber diameters of about $100 \mathrm{~nm}$. The capacitance retention was retained to approximately $90 \%$ after 6000 cycles of charge/discharge.

Wang et al. [101] utilized OS/polyethylene mixtures for the production of carbon fibrous mats dedicated for use as high-performance anode material in lithium-ion batteries. The production process involved electro spinning followed by carbonization and thermal annealing in the presence of urea. The fibrous mats achieved specific capacities up to $445 \mathrm{mAh} / \mathrm{g}$, which are comparable to currently used polyacrylonitrile-derived carbon fibers.

Gonugunta et al. [102] successfully synthesized carbon nanoparticles from commercial Protobind 2400 Lignin by freeze drying the lignin solution and through carbonization of the resulting lignin nanoparticles in a tube furnace. The process yielded porous particles in the size range of 25 to $150 \mathrm{~nm}$.

Yiamsawas et al. [103] methacrylated KL, which was subsequently processed to particles with an extraordinary porous structure. The particles with diameters up to 2-3 $\mu \mathrm{m}$ were prepared in the absence of surfactants or in the presence of the surfactant Lutensol AT25 and were carbonized at $600{ }^{\circ} \mathrm{C}$ and $800{ }^{\circ} \mathrm{C}$. Structural parameters were analyzed by the BET method (see Table 4). The adsorption ability, which is the property mainly used in applications, was evaluated by using methylene blue as a model adsorbent. Carbon particles prepared from porous LNPs showed an adsorption capacity twice as high as the carbon particles prepared from pristine lignin.

Table 4. Oxygen and carbon composition determined by X-ray photoelectron spectroscopy (XPS) and structure parameters obtained by the Brunauer-Emmett-Teller (BET) method for samples before and after carbonization at different temperatures. Adapted with permission from [103]. Copyright 2017 American Chemical Society.

\begin{tabular}{ccccccc}
\hline Sample & $\begin{array}{c}\text { Carbonization } \\
\text { Temperature }\left({ }^{\circ} \mathbf{C}\right)\end{array}$ & $\mathbf{O}(\%)$ & $\mathbf{C ~ ( \% )}$ & $\begin{array}{c}\text { BET Surface } \\
\text { Area }\left(\mathbf{m}^{\mathbf{2}} / \mathbf{g}\right)\end{array}$ & $\begin{array}{c}\text { Average Pore } \\
\text { Volume }\left(\mathbf{c m}^{3} / \mathbf{g}\right)\end{array}$ & $\begin{array}{c}\text { Average Pore } \\
\text { Width }(\AA)\end{array}$ \\
\hline Pristine lignin & - & 27 & 73 & 5 & 0.017 & 16.5 \\
Porous LNP & - & 21.6 & 78.4 & 15 & 0.020 & 34.7 \\
Pristine lignin & 800 & 14.1 & 85.9 & 29 & 0.023 & 18.5 \\
Porous LNP & 600 & 17.2 & 82.8 & 202 & 0.123 & 14.7 \\
Porous LNP & 800 & 8 & 92 & 552 & 0.274 & 14.8 \\
\hline
\end{tabular}

Carbon dots are, due to their optical stability, low toxicity, biocompatibility and ease of functionalization, an interesting class of carbon nanoparticles [104-106]. Rai et al. [107] synthesized 
reduced fluorescence carbon dots (rFCDs) from lignosulfonate lignin using a microwave irradiation method previously described by Chen et al. [108]. This method includes a depolymerisation step in order to reach particle sizes of less than $10 \mathrm{~nm}$ and differs, therefore, from other production methods. A brief schematic representation of the whole process is given in Figure 8. The process resulted in cost-effective water-soluble rFCDs for bioimaging applications. The photoluminescent intensity maximum was found at $475 \mathrm{~nm}$ when excited with $440 \mathrm{~nm}$.

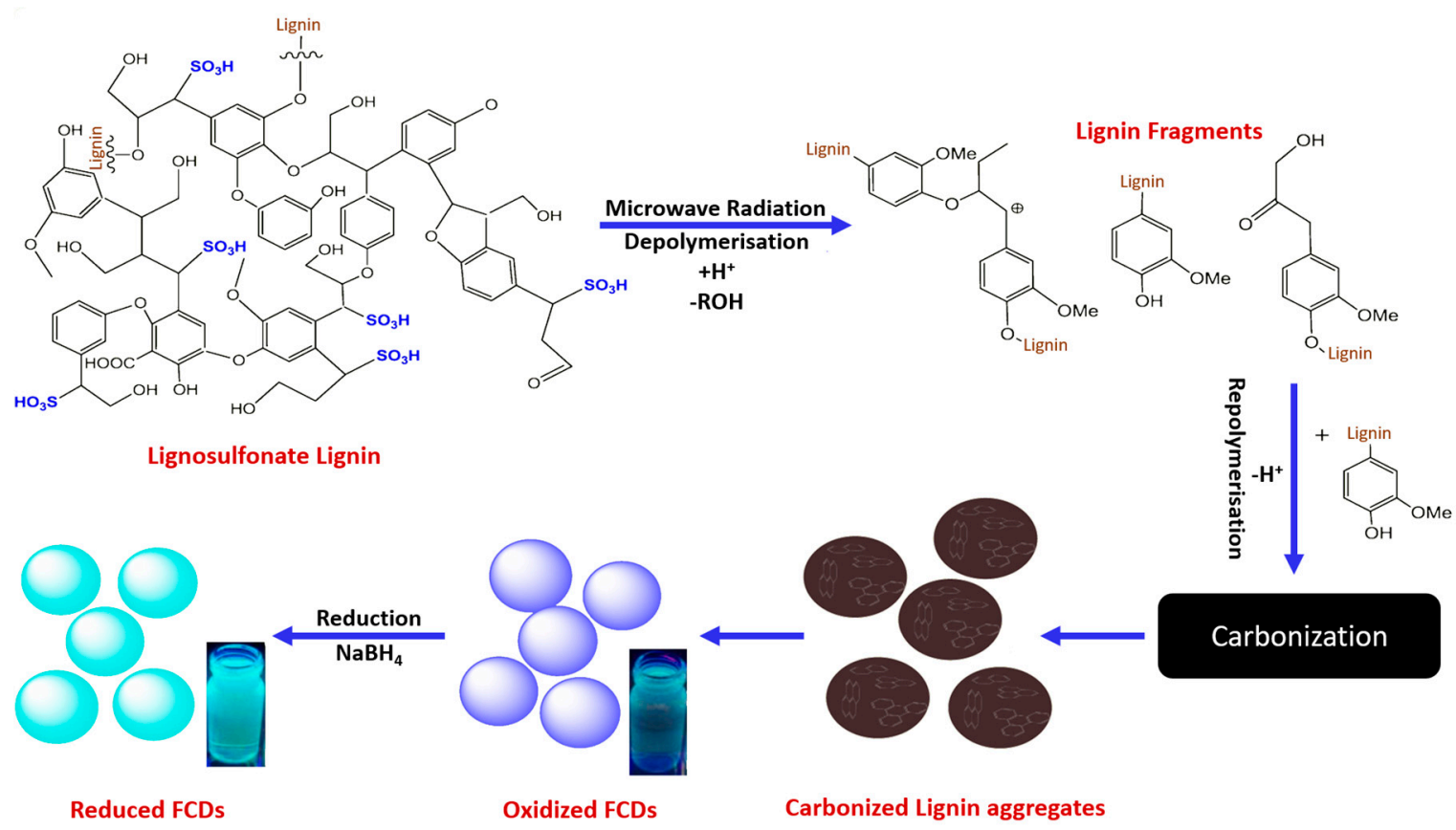

Figure 8. Schematic representation of the production procedure for reduced fluorescence carbon dots from lignosulfonate lignin in aqueous acidic media, including possible depolymerisation and formation reaction mechanisms in which sulfonate groups were neglected. Reprinted from [107], with permission from Elsevier.

\section{Application of Lignin Nanoparticles as Nano- and Microcarrier}

Currently, based on the number of published research papers, the use of lignin nanostructures in the medical field as drug carriers seems to be the most investigated field of application. Generally, the nanocarriers can be distinguished in two categories: (1) hollow particles where the carried substance is encapsulated; (2) solid and porous particles infused with the carried substance.

\subsection{Capsules, Hollow and Porous Structures}

In recent years, microencapsulation processes have gained significant interest in academic and industrial research [109-115]. Microencapsulation has potential applications in the delivery of soluble drugs [116,117], pesticides [118] and gene [119,120] and food additives [121]. The major problem for controlled release systems is the initial burst which releases a great amount of active agent causing an acutely high concentration and therefore, a failure of the controlled release [122,123]. Encapsulation might be key for this issue.

Lignin nano- and microcapsules for the transport of hydrophobic and hydrophilic substances with different releasing properties via miniemulsion polymerization are reported in literature $[103,124-126]$. Chen et al. [126] used allyl-grafted lignosulfonate to prepare capsules via ultrasonication in an oil-in-water miniemulsion. The method resulted in capsules with diameters ranging from 50 to $300 \mathrm{~nm}$. For the release study, the hydrophobic model drug coumarin- 6 was incorporated in the oil particle core by 
dissolving it in the oil phase before sonication. The capsules showed an entrapment capacity of $0.713 \mathrm{mmol} / \mathrm{g}$ based on the weight of modified lignosulfonate. The release study was conducted in aqueous surfactant-containing buffer solutions at $\mathrm{pH} 4$ and $\mathrm{pH}$ 7.4. The release kinetics showed an enhanced release rate at the lower $\mathrm{pH}$ value (see Figure 9a; dataset $\mathrm{pH} 7.4$ and $\mathrm{pH} 4$ ). This behavior might be ascribed to the destruction of acid-liable $\beta$-thiopropionate cross-linkages $[127,128]$ and weakening of the hydrophobicity of lignin's cross-linked shell by protonation of coumarin- 6 at low $\mathrm{pH}$-values [129]. Also, Tortora et al. [125] conducted a release study of coumarin-6 on lignin capsules. In this study, pure KL was used to produce capsules in a size range of 0.3 to $1.1 \mu \mathrm{m}$ depending on the cross-linking agent used. The addition of poly(ethylene glycol) diglycidyl ether (PEG) and $\mathrm{H}_{2} \mathrm{O}_{2}$ reduced the size of the capsules in comparison with the use of just sonication, where PEG achieved the smallest sizes. The biocompatibility study of theses capsules with Chinese hamster ovary cells shows promising results for a potential use in the biomedical field. The release study was conducted in water using the same surfactant and surfactant concentration as used by Chen et al. [126] but the $\mathrm{pH}$ value was not controlled by a buffer. Figure 9a shows also the release kinetics of the capsules made without cross-linking agent (LMC_5) and made with PEG (PEG-LMC_5). Both kinds of capsules released their cargo at a similar rate where almost $100 \%$ of entrapped Coumarin- 6 was released after $1 \mathrm{~h}$. However, the release rate differed significantly from the rates obtained by Chen et al. [126] which showed a maximum release of $60 \%$ after $48 \mathrm{~h}$.
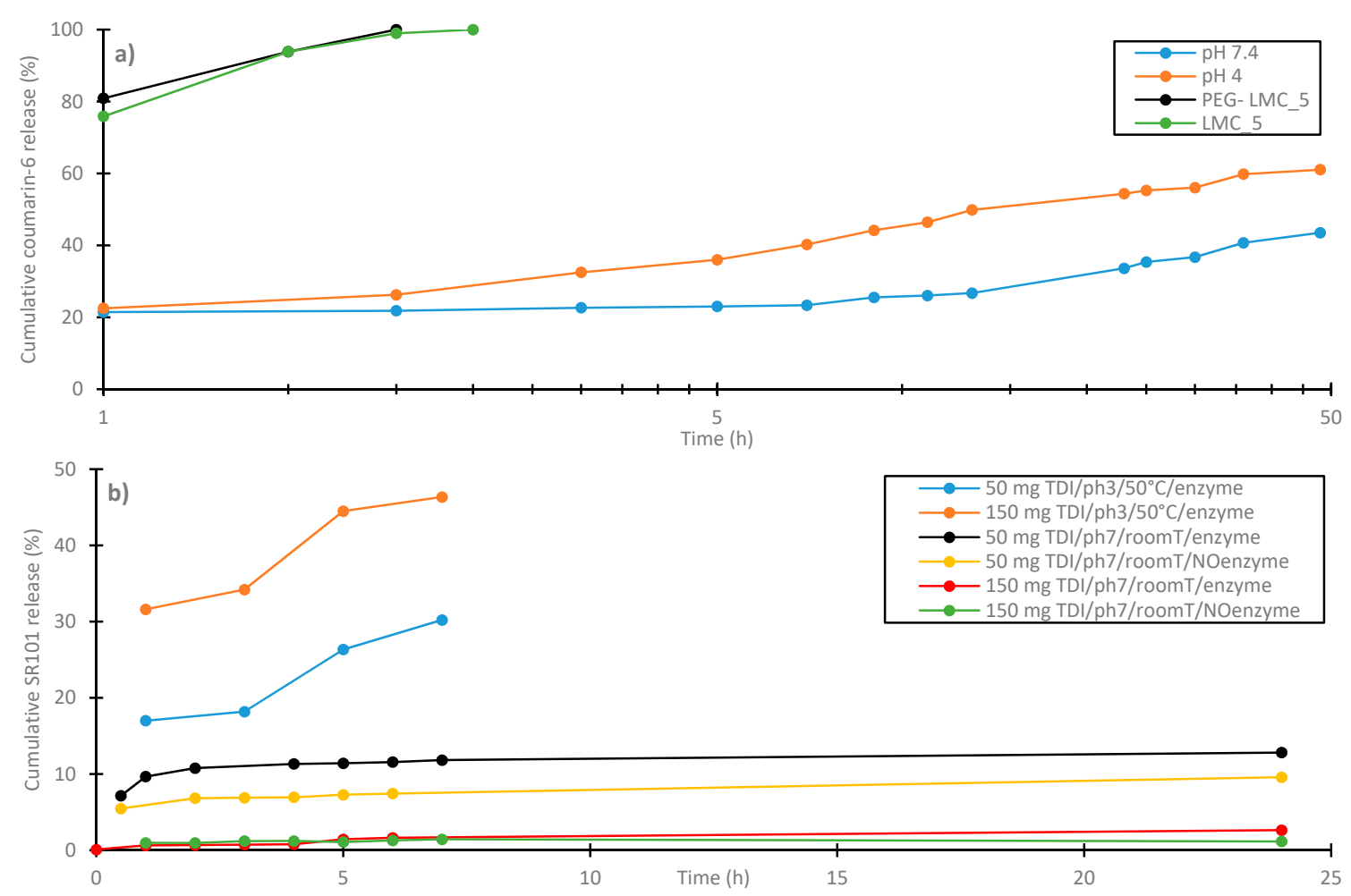

Figure 9. Releasing rates of hydrophobic Coumarin-6 and hydrophilic SR101 for different lignin capsules. (a) Coumanrin-6 releasing rate of capsules produced by Chen et al. [126] at $\mathrm{pH} 4$ and pH 7.4 (Adapted with permission from [126]. Copyright 2016 American Chemical Society) and capsules (PEG-LMC_5 and LMC_5) produced by Tortora et al. [125] (Adapted with permission from [125]. Copyright 2014 American Chemical Society); (b) SR101 releasing rate at different amounts of crosslinking agent TDI, pH values, temperatures and degradation by enzymes [124], published by The Royal Society of Chemistry.

Yiamsawas et al. [124] used interfacial polyaddition in inverse miniemulsions to prepare nanocapsules for hydrophilic loadings. Lignosulfonic acid sodium salt with 2,4-Toluene diisocyanate 
(TDI) as cross-linker resulted in capsules in a range of 150-200 nm. A releasing study with hydrophilic fluorescent dye sulforhodamine (SR101) including the investigation of the biodegradability was conducted. The cleavage of the cross-linked lignin shell was studied by using a laccase enzyme from the fungus Xylaria sp. IBWF A55-2009, which has an important role in the recycling of lignin [130]. Figure $9 \mathrm{~b}$ shows the releasing kinetics of SR101-filled capsules with different amounts of cross-linking agent TDI at $\mathrm{pH}$ values of 3 and 7 and with and without degradation by enzymes. The results clearly show that less crosslinking agent, higher temperatures, lower $\mathrm{pH}$ values and degradation by enzymes increase the release rate.

In a further work, Yiamsawas et al [103] was producing nano- and microparticles with variable morphologies using KL modified by esterification with methacrylic anhydride in a combined miniemulsion polymerization, with subsequent solvent evaporation. The solid nanoparticles, nanocapsules and porous microparticles were loaded with 2-propylpyridine and release was studied following the method of Dowding et al. [131]. 2-propylpyridine was used since it is soluble in the oil phase and partially soluble in the aqueous phase. Figure 10a shows the release study results. Solid and porous particles show the lowest rates whereas particles with an oil core and lignin shell show a higher rate. In addition, the type of oil used as core seems to influence the releasing rate. Studies with degradation, using the enzyme laccase, were conducted and indicate a higher releasing rate when treated with enzymes (see Figure 10b).
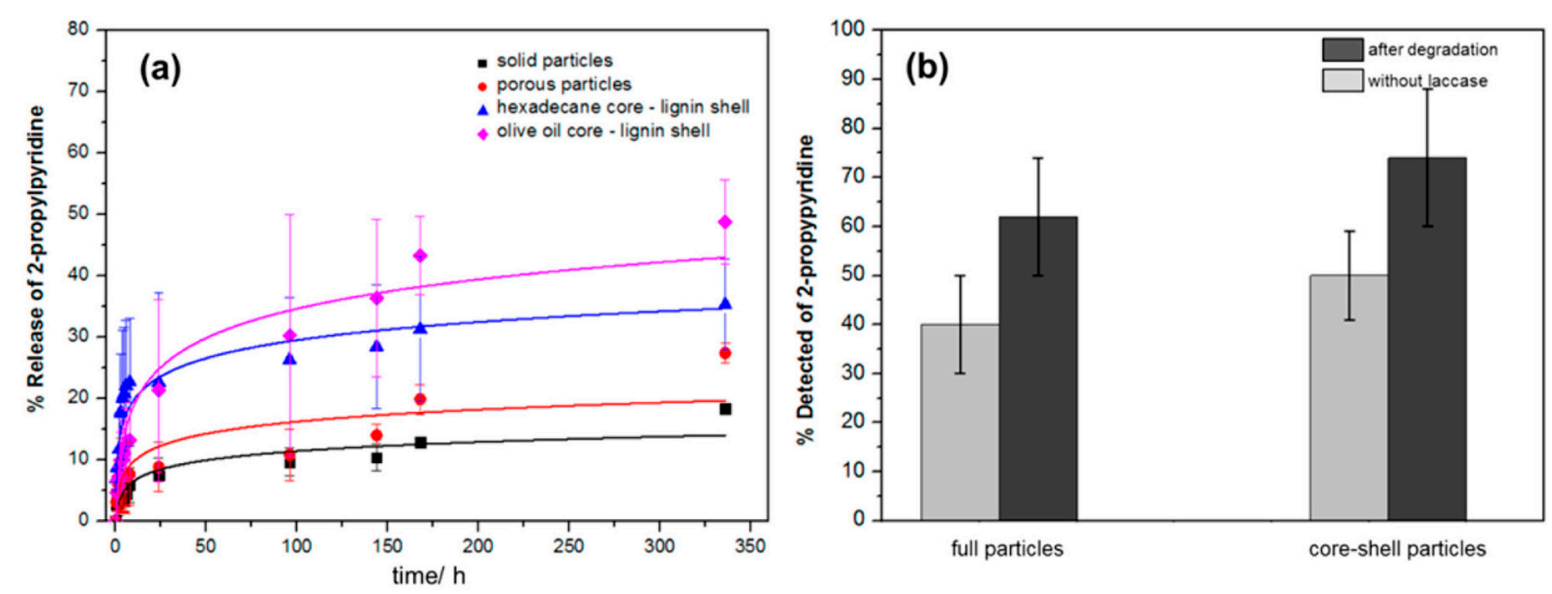

Figure 10. (a) Release profile of 2-propylpyridine from lignin nanocarriers with varying morphology, core or surfactant. (b) Amount of 2-propylpyridine released after $24 \mathrm{~h}$ with and without enzymatic degradation of solid and core-shell nanocarriers with enzymes after $24 \mathrm{~h}$. Reprinted with permission from [103]. Copyright 2017 American Chemical Society.

Ten et al. [132] synthesized lignin nanotubes (LNT) from different sources using a sacrificial alumina membrane template. Those nanotubes are intended to be used in the medical therapeutic field and to substitute carbon nanotubes (CNT) whose use has caused concerns due to their cytotoxicity $[133,134]$. Cytotoxicity studies with human cervical adenocarcinoma (HeLa) cells showed a toleration threshold 10 times higher when compared to CNTs. DNA can successfully adsorb on the LNTs and leads to transfection in HeLa cells. Furthermore, it appears that the lignin-isolation procedure is mainly influencing the cytotoxicity, and that the transfection efficiency is also influenced by the lignin source.

Zhong et al. [135] encapsulated the enzyme horseradish peroxidase in sodium lignosulfonate reverse micelles. Free enzymes easily lose their activity when exposed to the natural environment whereas immobilized enzymes can gain stability, adjust reactions, and improve recyclability. The immobilized enzyme showed enhanced activity compared to free horseradish peroxidase at acidic and low-temperature environments. Those properties might allow applications in the processing 
of phenolic wastewater due to the catalytic polymerization property of horseradish peroxidase being now viable under harsher conditions.

A layer-by-layer method was used by Wand and Zhao [136] in order to encapsulate the herbicide picloram (PLR) with alternating layers of chitosan and sodium lignosulfonate. The release time of the PLR and its photo stability was adjustable according to the number of layers used. The time required for the release of 50\% PLR from the capsules was $0.433 \mathrm{~h}, 1.015 \mathrm{~h}$ and $2.257 \mathrm{~h}$ for 4,8 and 12 layers, respectively.

\subsection{Solid and Porous Particles/Structures}

In the case of solid particles, the active agent is incorporated in the LNPs already during the precipitation step as shown by Figueiredo et al. [137] and Dai et al. [138].

Dai et al. [138] precipitated LNPs using ethanol, methanol and tetrahydrofuran (THF) as solvent and water or aqueous $\mathrm{Fe}_{3} \mathrm{O}_{4}$ nanodispersion as antisolvent. Resveratrol (RSV), a bioactive molecule, was used as active ingredient. In order to incorporate RSV in the LNP, it was mixed with the solvent and incorporated during the precipitation process and resulted in an average hydrodynamic LNP diameter of $180 \mathrm{~nm}$. Cytological and animal tests were conducted and showed good anticancer effects, enhanced by in vitro RSV release, stability and accumulation and better tumor reduction (see Figure 11). Also, the LNPs had a relatively high drug-loading capacity of over $20 \mathrm{wt} \%$ as well as reduced adverse effects compared to free RSV.

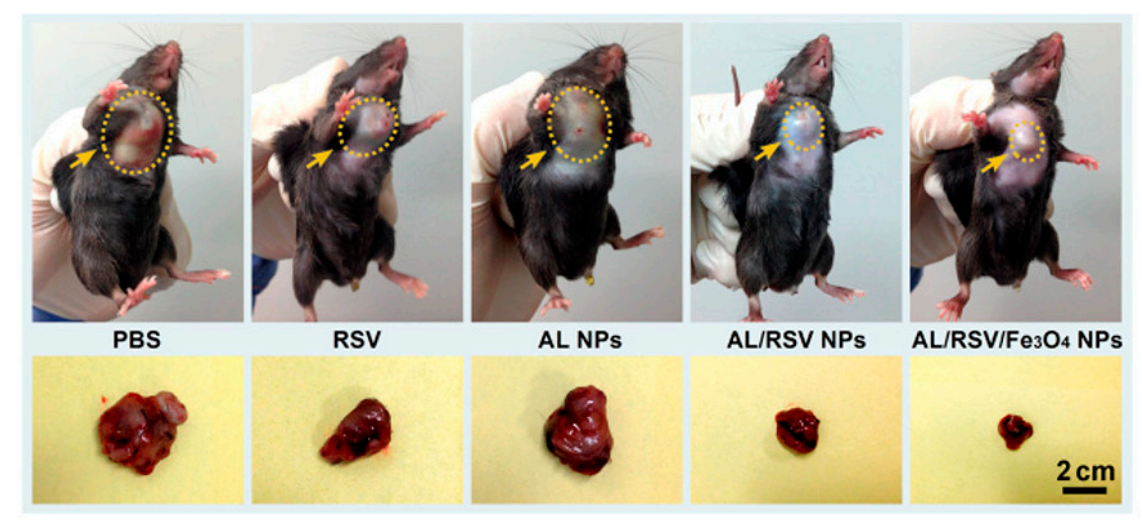

Figure 11. Tumor photographs of mice treated with different nanoparticles, pure Resveratrol and phosphate-buffered saline (PBS) as control. AL/RSV $/ \mathrm{Fe}_{3} \mathrm{O}_{4}$, an LNP containing Resveratrol and $\mathrm{Fe}_{3} \mathrm{O}_{4}$ showed the best performance and could reduce the tumor size significantly. Adapted with permission from [138]. Copyright 2017 American Chemical Society.

Figueiredo et al. [137] used similar methods for the preparation of $\mathrm{Fe}_{3} \mathrm{O}_{4}$ LNPs, but the precipitation step was conducted via a dialysis process. The cytotoxic test agents, sorafenib (SFN) and benzazulene (BZL), and a water-soluble drug, capecitabine (CAP), were also incorporated in the LNPs during the precipitation process. All LNPs exhibited low cytotoxicity at concentrations up to $100 \mathrm{mg} / \mathrm{mL}$ in different cell lines. Overall, these LNPs showed important features for drug delivery and biomedical applications, including biocompatibility, very good stability, an ability to load hydrophobic drugs and sustain their release, and good cellular interaction. Furthermore, the particles including $\mathrm{Fe}_{3} \mathrm{O}_{4}$ showed superparamagnetic behavior, which makes them promising for magnetic targeting and magnetic-resonance imaging.

\section{Conclusions and Outlook}

Different application fields of lignin from micro- to nanosize were identified from the literature ranging from simple polymer blends with improved mechanical properties to promising drug carriers 
for cancer treatment. Consequently, the possibility of applying lignin in high-value pharma fields was also shown. The parameters influencing the properties of the final product include the lignin source, the method of extracting lignin from the lignocellulose raw material, the production/precipitation method of the nanoparticles which influences the surface properties of the particles and, in the case of polymer blends, the processing/blending method.

This is clearly an opportunity to tailor the properties of the final product by optimizing the whole process chain. On the other hand, considering a whole biorefinery in which switching raw materials and lignin-extraction methods is not easily possible, it is crucial to determine suitable final products for existing processes. Moreover, changing raw lignocellulose quality might influence the LNP and final product quality. Nevertheless, a large number of potential high-value applications are within the range of vision for micro- and nanosize lignin particles.

Acknowledgments: The authors acknowledge the TU Wien University Library for financial support through its Open Access Funding Program.

Author Contributions: Stefan Beisl wrote and edited the manuscript with significant input and editing from Anton Friedl and Angela Miltner.

Conflicts of Interest: The authors declare no conflict of interest.

\section{Abbreviations}

AL

ATRP

BHA

Bio-PTT

BZL

CAP

CAT

CFU

$\mathrm{CH}$

CNC

CNT

DEAEMA

DPPH

g-PLA

HeLa

KL

LNP

LNT

NMP

OS

PBS

PDAC

PEG

PLA

PLR

PS

PVA

RAFT

rFCDs

RSA

RSV
Alkali lignin

Atom transfer radical polymerization

Butylated hydroxyanisole

Bio-poly(trimethylene terephthalate)

Benzazulene

Capecitabine

Cellulose triacetate

Colony-forming unit

Chitosan

Cellulose nanocrystals

Carbon nanotube

2-(diethyl-amino)ethyl methacrylate

2,2-diphenyl-1-picrylhydrazyl

Glycidyl methacrylate grafted polylactic acid

Human cervical adenocarcinoma

Kraft lignin

Lignin nanoparticles

Lignin nanotubes

Nitroxide-mediated radical polymerization

Organosolv lignin

Phosphate-buffered saline

Polydiallyldimethylammonium chloride

Poly(ethylene glycol) diglycidyl ether

Polylactic acid

Picloram

Polystyrene

Polyvinyl alcohol

Reversible addition-fragmentation chain transfer

Reduced fluorescence carbon dots

Radical scavenging activity

Resveratrol 


$\begin{array}{ll}\text { SFN } & \text { Sorafenib } \\ \text { SPF } & \text { Sun protection factor } \\ \text { SR101 } & \text { Hydrophilic fluorescent dye sulforhodamine } \\ \text { SRSA } & \text { Superoxide radical scavenging activity } \\ \text { TDI } & \text { 2,4-Toluene diisocyanate } \\ \text { WG } & \text { Wheat gluten }\end{array}$

\section{References}

1. Zhang, M.L.; Fan, Y.T.; Xing, Y.; Pan, C.M.; Zhang, G.S.; Lay, J.J. Enhanced biohydrogen production from cornstalk wastes with acidification pretreatment by mixed anaerobic cultures. Biomass Bioenergy 2007, 31, 250-254. [CrossRef]

2. Tuck, C.O.; Perez, E.; Horvath, I.T.; Sheldon, R.A.; Poliakoff, M. Valorization of Biomass: Deriving More Value from Waste. Science 2012, 337, 695-699. [CrossRef] [PubMed]

3. Boerjan, W.; Ralph, J.; Baucher, M. Lignin Biosynthesis. Annu. Rev. Plant Biol. 2003, 54, 519-546. [CrossRef] [PubMed]

4. Sannigrahi, P.; Ragauskas, A.J. Characterization of Fermentation Residues from the Production of Bio-Ethanol from Lignocellulosic Feedstocks. J. Biobased Mater. Bioenergy 2011, 5, 514-519. [CrossRef]

5. Holladay, J.E.; White, J.F.; Bozell, J.J.; Johnson, D. Top Value-Added Chemicals from Biomass-Volume II, Results of Screening for Potential Candidates from Biorefinery Lignin; United States Department of Energy: Richland, WA, USA, 2007; Volume II.

6. Graichen, F.H.M.; Grigsby, W.J.; Hill, S.J.; Raymond, L.G.; Sanglard, M.; Smith, D.A.; Thorlby, G.J.; Torr, K.M.; Warnes, J.M. Yes, we can make money out of lignin and other bio-based resources. Ind. Crops Prod. 2017, 106, 74-85. [CrossRef]

7. Calvo-Flores, F.G.; Dobado, J.A. Lignin as Renewable Raw Material. ChemSusChem 2010, 3, 1227-1235. [CrossRef] [PubMed]

8. Chandra, R.P.; Bura, R.; Mabee, W.E.; Berlin, A.; Pan, X.; Saddler, J.N. Substrate Pretreatment: The Key to Effective Enzymatic Hydrolysis of Lignocellulosics? In Biofuels; Springer: Berlin/Heidelberg, Germany, 2007; Volume 108, pp. 67-93.

9. Li, C.; Zhao, X.; Wang, A.; Huber, G.W.; Zhang, T. Catalytic Transformation of Lignin for the Production of Chemicals and Fuels. Chem. Rev. 2015, 115, 11559-11624. [CrossRef] [PubMed]

10. Gellerstedt, G.; Henriksson, G. Lignins: Major Sources, Structure and Properties. In Monomers, Polymers and Composites from Renewable Resources; Elsevier: Amsterdam, The Netherlands, 2008; pp. 201-224.

11. Ragauskas, A.J.; Beckham, G.T.; Biddy, M.J.; Chandra, R.; Chen, F.; Davis, M.F.; Davison, B.H.; Dixon, R.A.; Gilna, P.; Keller, M.; et al. Lignin valorization: Improving lignin processing in the biorefinery. Science 2014, 344, 1246843. [CrossRef] [PubMed]

12. Hussain, F. Review article: Polymer-matrix Nanocomposites, Processing, Manufacturing, and Application: An Overview. J. Compos. Mater. 2006, 40, 1511-1575. [CrossRef]

13. Beisl, S.; Miltner, A.; Friedl, A. Lignin from Micro- to Nanosize: Production Methods. Int. J. Mol. Sci. 2017, 18, 1244. [CrossRef] [PubMed]

14. Doherty, W.O.S.; Mousavioun, P.; Fellows, C.M. Value-adding to cellulosic ethanol: Lignin polymers. Ind. Crops Prod. 2011, 33, 259-276. [CrossRef]

15. Laurichesse, S.; Avérous, L. Chemical modification of lignins: Towards biobased polymers. Prog. Polym. Sci. 2014, 39, 1266-1290. [CrossRef]

16. Yang, W.; Fortunati, E.; Dominici, F.; Kenny, J.M.M.; Puglia, D. Effect of processing conditions and lignin content on thermal, mechanical and degradative behavior of lignin nanoparticles/polylactic (acid) bionanocomposites prepared by melt extrusion and solvent casting. Eur. Polym. J. 2015, 71, 126-139. [CrossRef]

17. Yang, W.; Fortunati, E.; Dominici, F.; Giovanale, G.; Mazzaglia, A.; Balestra, G.M.; Kenny, J.M.; Puglia, D. Synergic effect of cellulose and lignin nanostructures in PLA based systems for food antibacterial packaging. Eur. Polym. J. 2016, 79, 1-12. [CrossRef]

18. Auras, R.; Harte, B.; Selke, S. An Overview of Polylactides as Packaging Materials. Macromol. Biosci. 2004, 4, 835-864. [CrossRef] [PubMed] 
19. Yang, W.; Kenny, J.M.; Puglia, D. Structure and properties of biodegradable wheat gluten bionanocomposites containing lignin nanoparticles. Ind. Crops Prod. 2015, 74, 348-356. [CrossRef]

20. Kayserilioglu, B.Ş.; Bakir, U.; Yilmaz, L.; Akkaş, N. Drying Temperature and Relative Humidity Effects on Wheat Gluten Film Properties. J. Agric. Food Chem. 2003, 51, 964-968. [CrossRef] [PubMed]

21. Tunc, S.; Angellier, H.; Cahyana, Y.; Chalier, P.; Gontard, N.; Gastaldi, E. Functional properties of wheat gluten/montmorillonite nanocomposite films processed by casting. J. Memb. Sci. 2007, 289, 159-168. [CrossRef]

22. Duval, A.; Molina-Boisseau, S.; Chirat, C. Comparison of Kraft lignin and lignosulfonates addition to wheat gluten-based materials: Mechanical and thermal properties. Ind. Crops Prod. 2013, 49, 66-74. [CrossRef]

23. Gontard, N.; Duchez, C.; Cuq, J.-L.; Gulibert, S. Edible composite films of wheat gluten and lipids: Water vapour permeability and other physical properties. Int. J. Food Sci. Technol. 2007, 29, 39-50. [CrossRef]

24. Mojumdar, S.C.; Moresoli, C.; Simon, L.C.; Legge, R.L. Edible wheat gluten (WG) protein films. J. Therm. Anal. Calorim. 2011, 104, 929-936. [CrossRef]

25. Del Saz-Orozco, B.; Oliet, M.; Alonso, M.V.; Rojo, E.; Rodríguez, F. Formulation optimization of unreinforced and lignin nanoparticle-reinforced phenolic foams using an analysis of variance approach. Compos. Sci. Technol. 2012, 72, 667-674. [CrossRef]

26. Landrock, A.H. Handbook of Plastic Foams: Types, Properties, Manufacture and Applications; Elsevier: Amsterdam, The Netherlands, 1995.

27. Shen, H.; Nutt, S. Mechanical characterization of short fiber reinforced phenolic foam. Compos. Part A Appl. Sci. Manuf. 2003, 34, 899-906. [CrossRef]

28. Shen, H.; Lavoie, A.J.; Nutt, S.R. Enhanced peel resistance of fiber reinforced phenolic foams. Compos. Part A Appl. Sci. Manuf. 2003, 34, 941-948. [CrossRef]

29. Nevárez, L.A.M.; Casarrubias, L.B.; Celzard, A.; Fierro, V.; Muñoz, V.T.; Davila, A.C.; Lubian, J.R.T.; Sánchez, G.G. Biopolymer-based nanocomposites: Effect of lignin acetylation in cellulose triacetate films. Sci. Technol. Adv. Mater. 2011, 12, 45006. [CrossRef] [PubMed]

30. Arthanareeswaran, G.; Thanikaivelan, P.; Srinivasn, K.; Mohan, D.; Rajendran, M. Synthesis, characterization and thermal studies on cellulose acetate membranes with additive. Eur. Polym. J. 2004, 40, 2153-2159. [CrossRef]

31. Yang, W.; Dominici, F.; Fortunati, E.; Kenny, J.M.; Puglia, D. Effect of lignin nanoparticles and masterbatch procedures on the final properties of glycidyl methacrylate-g-poly (lactic acid) films before and after accelerated UV weathering. Ind. Crops Prod. 2015, 77, 833-844. [CrossRef]

32. Yang, W.; Owczarek, J.S.S.; Fortunati, E.; Kozanecki, M.; Mazzaglia, A.; Balestra, G.M.M.; Kenny, J.M.M.; Torre, L.; Puglia, D. Antioxidant and antibacterial lignin nanoparticles in polyvinyl alcohol/chitosan films for active packaging. Ind. Crops Prod. 2016, 94, 800-811. [CrossRef]

33. Nair, S.S.; Sharma, S.; Pu, Y.; Sun, Q.; Pan, S.; Zhu, J.Y.; Deng, Y.; Ragauskas, A.J. High Shear Homogenization of Lignin to Nanolignin and Thermal Stability of Nanolignin-Polyvinyl Alcohol Blends. ChemSusChem 2014, 7, 3513-3520. [CrossRef] [PubMed]

34. Kubo, S.; Kadla, J.F. The formation of strong intermolecular interactions in immiscible blends of poly(vinyl alcohol) (PVA) and lignin. Biomacromolecules 2003, 4, 561-567. [CrossRef] [PubMed]

35. Liu, P.; Chen, W.; Liu, Y.; Bai, S.; Wang, Q. Thermal melt processing to prepare halogen-free flame retardant poly(vinyl alcohol). Polym. Degrad. Stab. 2014, 109, 261-269. [CrossRef]

36. Gupta, A.K.; Mohanty, S.; Nayak, S.K. Influence of addition of vapor grown carbon fibers on mechanical, thermal and biodegradation properties of lignin nanoparticle filled bio-poly(trimethylene terephthalate) hybrid nanocomposites. RSC Adv. 2015, 5, 56028-56036. [CrossRef]

37. Zhang, J. Study of poly(trimethylene terephthalate) as an engineering thermoplastics material. J. Appl. Polym. Sci. 2004, 91, 1657-1666. [CrossRef]

38. Alexandre, M.; Dubois, P. Polymer-layered silicate nanocomposites: Preparation, properties and uses of a new class of materials. Mater. Sci. Eng. R Rep. 2000, 28, 1-63. [CrossRef]

39. Cai, X.; Riedl, B.; Zhang, S.Y.; Wan, H. The impact of the nature of nanofillers on the performance of wood polymer nanocomposites. Compos. Part A Appl. Sci. Manuf. 2008, 39, 727-737. [CrossRef]

40. Rhim, J.-W.; Mohanty, A.K.; Singh, S.P.; Ng, P.K.W. Effect of the processing methods on the performance of polylactide films: Thermocompression versus solvent casting. J. Appl. Polym. Sci. 2006, 101, 3736-3742. [CrossRef] 
41. Jiang, C.; He, H.; Jiang, H.; Ma, L.; Jia, D.M. Nano-lignin filled natural rubber composites: Preparation and characterization. Express Polym. Lett. 2013, 7, 480-493. [CrossRef]

42. Lanzalunga, O.; Bietti, M. Photo- and radiation chemical induced degradation of lignin model compounds. J. Photochem. Photobiol. B Biol. 2000, 56, 85-108. [CrossRef]

43. Barsberg, S.; Elder, T.; Felby, C. Lignin-Quinone Interactions: Implications for Optical Properties of Lignin. Chem. Mater. 2003, 15, 649-655. [CrossRef]

44. Yearla, S.R.; Padmasree, K. Preparation and characterisation of lignin nanoparticles: Evaluation of their potential as antioxidants and UV protectants. J. Exp. Nanosci. 2016, 11, 289-302. [CrossRef]

45. Li, H.; Deng, Y.; Wu, H.; Ren, Y.; Qiu, X.; Zheng, D.; Li, C. Self-assembly of kraft lignin into nanospheres in dioxane-water mixtures. Holzforschung 2016, 70, 725-731. [CrossRef]

46. Zimniewska, M.; Kozłowski, R.; Batog, J. Nanolignin Modified Linen Fabric as a Multifunctional Product. Mol. Cryst. Liq. Cryst. 2008, 484, 43/(409)-50/(416). [CrossRef]

47. Qian, Y.; Qiu, X.; Zhu, S. Sunscreen Performance of Lignin from Different Technical Resources and Their General Synergistic Effect with Synthetic Sunscreens. ACS Sustain. Chem. Eng. 2016, 4, 4029-4035. [CrossRef]

48. Qian, Y.; Qiu, X.; Zhu, S. Lignin: A nature-inspired sun blocker for broad-spectrum sunscreens. Green Chem. 2015, 17, 320-324. [CrossRef]

49. Qian, Y.; Zhong, X.; Li, Y.; Qiu, X. Fabrication of uniform lignin colloidal spheres for developing natural broad-spectrum sunscreens with high sun protection factor. Ind. Crops Prod. 2017, 101, 54-60. [CrossRef]

50. Cazacu, G.; Capraru, M.; Popa, V.I. Advances in Natural Polymers; Thomas, S., Visakh, P.M., Mathew, A.P., Eds.; Advanced Structured Materials; Springer: Berlin/Heidelberg, Germany, 2013; Volume 18.

51. Nada, A.M.A.; El-Diwany, A.I.; Elshafei, A.M. Infrared and antimicrobial studies on different lignins. Acta Biotechnol. 1989, 9, 295-298. [CrossRef]

52. Zemek, J.; Košíková, B.; Augustín, J.; Joniak, D. Antibiotic properties of lignin components. Folia Microbiol. (Praha) 1979, 24, 483-486. [CrossRef] [PubMed]

53. Sláviková, E.; Košíková, B. Inhibitory effect of lignin by-products of pulping on yeast growth. Folia Microbiol. Off. J. Inst. Microbiol. Acad. Sci. Czech Repub. 1994, 39, 241-243. [CrossRef]

54. Telysheva, G.; Dizhbite, T.; Lebedeva, G.; Nikoleava, V. Lignin products for decontamination of environment objects from pathogenic microorganisms and pollutants. In Proceedings of the 7th ILI Forum, Barcelona, Spain, 27-28 April 2005; pp. 71-74.

55. Panáček, A.; Kolář, M.; Večeřová, R.; Prucek, R.; Soukupová, J.; Kryštof, V.; Hamal, P.; Zbořil, R.; Kvítek, L. Antifungal activity of silver nanoparticles against Candida spp. Biomaterials 2009, 30, 6333-6340. [CrossRef] [PubMed]

56. Lara, H.H.; Garza-Treviño, E.N.; Ixtepan-Turrent, L.; Singh, D.K. Silver nanoparticles are broad-spectrum bactericidal and virucidal compounds. J. Nanobiotechnol. 2011, 9, 30. [CrossRef] [PubMed]

57. Ahamed, M.; AlSalhi, M.S.; Siddiqui, M.K.J. Silver nanoparticle applications and human health. Clin. Chim. Acta 2010, 411, 1841-1848. [CrossRef] [PubMed]

58. Stern, S.T.; McNeil, S.E. Nanotechnology Safety Concerns Revisited. Toxicol. Sci. 2008, 101, 4-21. [CrossRef] [PubMed]

59. Jeong, E.; Im, W.-T.; Kim, D.-H.; Kim, M.-S.; Kang, S.; Shin, H.-S.; Chae, S.-R. Different susceptibilities of bacterial community to silver nanoparticles in wastewater treatment systems. J. Environ. Sci. Heal. Part A 2014, 49, 685-693. [CrossRef] [PubMed]

60. Walser, T.; Limbach, L.K.; Brogioli, R.; Erismann, E.; Flamigni, L.; Hattendorf, B.; Juchli, M.; Krumeich, F.; Ludwig, C.; Prikopsky, K.; et al. Persistence of engineered nanoparticles in a municipal solid-waste incineration plant. Nat. Nanotechnol. 2012, 7, 520-524. [CrossRef] [PubMed]

61. Popa, V.I.; Capraru, A.M.; Grama, S.; Maluţan, T. Nanoparticles based on modified lignins with biocide properties. Cellul. Chem. Technol. 2011, 45, 221-226.

62. Gîlcă, I.-A.; Popa, V.I. Study on Biocidal Properties of Some Nanoparticles Based on Epoxy Lignin. Cellul. Chem. Technol. 2013, 47, 3-4.

63. Schaad, N.W.; Committee, A.P.S.B. Laboratory Guide for Identification of Plant Pathogenic Bacteria; APS Press: St. Paul, MN, USA, 1988.

64. Quattrucci, A.; Ovidi, E.; Tiezzi, A.; Vinciguerra, V.; Balestra, G.M. Biological control of tomato bacterial speck using Punica granatum fruit peel extract. Crop Prot. 2013, 46, 18-22. [CrossRef] 
65. Waleron, M.; Waleron, K.; Lojkowska, E. Characterization of Pectobacterium carotovorum subsp. odoriferum causing soft rot of stored vegetables. Eur. J. Plant Pathol. 2014, 139, 457-469. [CrossRef]

66. Richter, A.P.; Brown, J.S.; Bharti, B.; Wang, A.; Gangwal, S.; Houck, K.; Cohen Hubal, E.A.; Paunov, V.N.; Stoyanov, S.D.; Velev, O.D. An environmentally benign antimicrobial nanoparticle based on a silver-infused lignin core. Nat. Nanotechnol. 2015, 10, 817-823. [CrossRef] [PubMed]

67. Richter, A.P.; Bharti, B.; Armstrong, H.B.; Brown, J.S.; Plemmons, D.; Paunov, V.N.; Stoyanov, S.D.; Velev, O.D. Synthesis and characterization of biodegradable lignin nanoparticles with tunable surface properties. Langmuir 2016, 32, 6468-6477. [CrossRef] [PubMed]

68. Lu, F.-J.; Chu, L.-H.; Gau, R.-J. Free radical-scavenging properties of lignin. Nutr. Cancer 1998, 30, 31-38. [CrossRef] [PubMed]

69. Dizhbite, T.; Telysheva, G.; Jurkjane, V.; Viesturs, U. Characterization of the radical scavenging activity of lignins - natural antioxidants. Bioresour. Technol. 2004, 95, 309-317. [CrossRef] [PubMed]

70. Hsu, B.; Coupar, I.M.; Ng, K. Antioxidant activity of hot water extract from the fruit of the Doum palm, Hyphaene thebaica. Food Chem. 2006, 98, 317-328. [CrossRef]

71. Lu, Q.; Zhu, M.; Zu, Y.; Liu, W.; Yang, L.; Zhang, Y.; Zhao, X.; Zhang, X.; Zhang, X.; Li, W. Comparative antioxidant activity of nanoscale lignin prepared by a supercritical antisolvent (SAS) process with non-nanoscale lignin. Food Chem. 2012, 135, 63-67. [CrossRef]

72. Pan, X.; Kadla, J.F.; Ehara, K.; Gilkes, N.; Saddler, J.N. Organosolv Ethanol Lignin from Hybrid Poplar as a Radical Scavenger: Relationship between Lignin Structure, Extraction Conditions, and Antioxidant Activity. J. Agric. Food Chem. 2006, 54, 5806-5813. [CrossRef] [PubMed]

73. Ge, Y.; Wei, Q.; Li, Z. Preparation and evaluation of the free radical scavenging activities of nanoscale lignin biomaterials. BioResources 2014, 9, 6699-6706. [CrossRef]

74. Li, Z.; Ge, Y. Extraction of lignin from sugar cane bagasse and its modification into a high performance dispersant for pesticide formulations. J. Braz. Chem. Soc. 2011, 22, 1866-1871. [CrossRef]

75. Byun, Y.; Kim, Y.T.; Whiteside, S. Characterization of an antioxidant polylactic acid (PLA) film prepared with $\alpha$-tocopherol, BHT and polyethylene glycol using film cast extruder. J. Food Eng. 2010, 100, 239-244. [CrossRef]

76. Domenek, S.; Louaifi, A.; Guinault, A.; Baumberger, S. Potential of Lignins as Antioxidant Additive in Active Biodegradable Packaging Materials. J. Polym. Environ. 2013, 21, 692-701. [CrossRef]

77. Maag, H. Fatty acid derivatives: Important surfactants for household, cosmetic and industrial purposes. J. Am. Oil Chem. Soc. 1984, 61, 259-267. [CrossRef]

78. Morán, C.; Clapés, P.; Comelles, F.; García, T.; Pérez, L.; Vinardell, P.; Mitjans, M.; Infante, M.R. Chemical Structure/Property Relationship in Single-Chain Arginine Surfactants. Langmuir 2001, 17, 5071-5075. [CrossRef]

79. Von Rybinski, W.; Hill, K. Alkyl Polyglycosides-Properties and Applications of a new Class of Surfactants. Angew. Chem. Int. Ed. 1998, 37, 1328-1345. [CrossRef]

80. Silmore, K.S.; Gupta, C.; Washburn, N.R. Tunable Pickering emulsions with polymer-grafted lignin nanoparticles (PGLNs). J. Colloid Interface Sci. 2016, 466, 91-100. [CrossRef] [PubMed]

81. Binks, B.P. Particles as surfactants-Similarities and differences. Curr. Opin. Colloid Interface Sci. 2002, 7, 21-41. [CrossRef]

82. Nypelö, T.E.; Carrillo, C.A.; Rojas, O.J. Lignin supracolloids synthesized from (W/O) microemulsions: Use in the interfacial stabilization of Pickering systems and organic carriers for silver metal. Soft Matter 2015, 11, 2046-2054. [CrossRef] [PubMed]

83. Wei, Z.; Yang, Y.; Yang, R.; Wang, C. Alkaline lignin extracted from furfural residues for pH-responsive Pickering emulsions and their recyclable polymerization. Green Chem. 2012, 14, 3230. [CrossRef]

84. Saigal, T.; Dong, H.; Matyjaszewski, K.; Tilton, R.D. Pickering Emulsions Stabilized by Nanoparticles with Thermally Responsive Grafted Polymer Brushes. Langmuir 2010, 26, 15200-15209. [CrossRef] [PubMed]

85. Alvarez, N.J.; Anna, S.L.; Saigal, T.; Tilton, R.D.; Walker, L.M. Interfacial Dynamics and Rheology of Polymer-Grafted Nanoparticles at Air-Water and Xylene-Water Interfaces. Langmuir 2012, 28, 8052-8063. [CrossRef] [PubMed]

86. Saleh, N.; Sarbu, T.; Sirk, K.; Lowry, G.V.; Matyjaszewski, K.; Tilton, R.D. Oil-in-Water Emulsions Stabilized by Highly Charged Polyelectrolyte-Grafted Silica Nanoparticles. Langmuir 2005, 21, 9873-9878. [CrossRef] [PubMed] 
87. Matyjaszewski, K. Atom Transfer Radical Polymerization (ATRP): Current Status and Future Perspectives. Macromolecules 2012, 45, 4015-4039. [CrossRef]

88. Nicolas, J.; Guillaneuf, Y.; Bertin, D.; Gigmes, D.; Charleux, B. Nitroxide-Mediated Polymerization. Polym. Sci. A Compr. Ref. 2012, 3, 277-350.

89. Chiefari, J.; Chong, Y.K.B.; Ercole, F.; Krstina, J.; Jeffery, J.; Le, T.P.T.; Mayadunne, R.T.A.; Meijs, G.F.; Moad, C.L.; Moad, G.; et al. Living Free-Radical Polymerization by Reversible Addition-Fragmentation Chain Transfer: The RAFT Process. Macromolecules 1998, 31, 5559-5562. [CrossRef]

90. Moad, G.; Rizzardo, E.; Thang, S.H. Radical addition-fragmentation chemistry in polymer synthesis. Polymer 2008, 49, 1079-1131. [CrossRef]

91. Gupta, C.; Washburn, N.R. Polymer-Grafted Lignin Surfactants Prepared via Reversible Addition-Fragmentation Chain-Transfer Polymerization. Langmuir 2014, 30, 9303-9312. [CrossRef] [PubMed]

92. Qian, Y.; Zhang, Q.; Qiu, X.; Zhu, S. $\mathrm{CO}_{2}$-responsive diethylaminoethyl-modified lignin nanoparticles and their application as surfactants for $\mathrm{CO}_{2} / \mathrm{N}_{2}$-switchable Pickering emulsions. Green Chem. 2014, 16, 4963-4968. [CrossRef]

93. Inagaki, M.; Yang, Y.; Kang, F. Carbon Nanofibers Prepared via Electrospinning. Adv. Mater. 2012, 24, $2547-2566$. [CrossRef] [PubMed]

94. Ray, S.C.; Saha, A.; Jana, N.R.; Sarkar, R. Fluorescent Carbon Nanoparticles: Synthesis, Characterization, and Bioimaging Application. J. Phys. Chem. C 2009, 113, 18546-18551. [CrossRef]

95. Schuster, J.; He, G.; Mandlmeier, B.; Yim, T.; Lee, K.T.; Bein, T.; Nazar, L.F. Spherical Ordered Mesoporous Carbon Nanoparticles with High Porosity for Lithium-Sulfur Batteries. Angew. Chem. 2012, 124, 3651-3655. [CrossRef]

96. Zhang, L.; Aboagye, A.; Kelkar, A.; Lai, C.; Fong, H. A review: Carbon nanofibers from electrospun polyacrylonitrile and their applications. J. Mater. Sci. 2014, 49, 463-480. [CrossRef]

97. Kadla, J.; Kubo, S.; Venditti, R.; Gilbert, R.; Compere, A.; Griffith, W. Lignin-based carbon fibers for composite fiber applications. Carbon N. Y. 2002, 40, 2913-2920. [CrossRef]

98. Hu, S.; Hsieh, Y.-L. Ultrafine microporous and mesoporous activated carbon fibers from alkali lignin. J. Mater. Chem. A 2013, 1, 11279. [CrossRef]

99. Hu, S.; Zhang, S.; Pan, N.; Hsieh, Y.-L. High energy density supercapacitors from lignin derived submicron activated carbon fibers in aqueous electrolytes. J. Power Sources 2014, 270, 106-112. [CrossRef]

100. Lai, C.; Zhou, Z.; Zhang, L.; Wang, X.; Zhou, Q.; Zhao, Y.; Wang, Y.; Wu, X.-F.; Zhu, Z.; Fong, H. Free-standing and mechanically flexible mats consisting of electrospun carbon nanofibers made from a natural product of alkali lignin as binder-free electrodes for high-performance supercapacitors. J. Power Sources 2014, 247, 134-141. [CrossRef]

101. Wang, S.X.; Yang, L.; Stubbs, L.P.; Li, X.; He, C. Lignin-derived fused electrospun carbon fibrous mats as high performance anode materials for lithium ion batteries. ACS Appl. Mater. Interfaces 2013, 5, 12275-12282. [CrossRef] [PubMed]

102. Gonugunta, P.; Vivekanandhan, S.; Mohanty, A.K.; Misra, M. A Study on Synthesis and Characterization of Biobased Carbon Nanoparticles from Lignin. World J. Nano Sci. Eng. 2012, 2, 148-153. [CrossRef]

103. Yiamsawas, D.; Beckers, S.J.; Lu, H.; Landfester, K.; Wurm, F.R. Morphology-Controlled Synthesis of Lignin Nanocarriers for Drug Delivery and Carbon Materials. ACS Biomater. Sci. Eng. 2017, 3, 2375-2383. [CrossRef]

104. Sun, Y.-P.; Zhou, B.; Lin, Y.; Wang, W.; Fernando, K.A.S.; Pathak, P.; Meziani, M.J.; Harruff, B.A.; Wang, X.; Wang, H.; et al. Quantum-Sized Carbon Dots for Bright and Colorful Photoluminescence. J. Am. Chem. Soc. 2006, 128, 7756-7757. [CrossRef] [PubMed]

105. Sun, Y.-P.; Wang, X.; Lu, F.; Cao, L.; Meziani, M.J.; Luo, P.G.; Gu, L.; Veca, L.M. Doped Carbon Nanoparticles as a New Platform for Highly Photoluminescent Dots. J. Phys. Chem. C. Nanomater. Interfaces 2008, 112, 18295-18298. [CrossRef] [PubMed]

106. Cao, L.; Wang, X.; Meziani, M.J.; Lu, F.; Wang, H.; Luo, P.G.; Lin, Y.; Harruff, B.A.; Veca, L.M.; Murray, D.; et al. Carbon Dots for Multiphoton Bioimaging. J. Am. Chem. Soc. 2007, 129, 11318-11319. [CrossRef] [PubMed]

107. Rai, S.; Singh, B.K.; Bhartiya, P.; Singh, A.; Kumar, H.; Dutta, P.K.; Mehrotra, G.K. Lignin derived reduced fluorescence carbon dots with theranostic approaches: Nano-drug-carrier and bioimaging. J. Lumin. 2017, 190, 492-503. [CrossRef]

108. Chen, W.; Hu, C.; Yang, Y.; Cui, J.; Liu, Y. Rapid Synthesis of Carbon Dots by Hydrothermal Treatment of Lignin. Materials (Basel) 2016, 9, 184. [CrossRef] [PubMed] 
109. Zhao, Q.; Han, B.; Wang, Z.; Gao, C.; Peng, C.; Shen, J. Hollow chitosan-alginate multilayer microcapsules as drug delivery vehicle: Doxorubicin loading and in vitro and in vivo studies. Nanomed. Nanotechnol. Biol. Med. 2007, 3, 63-74. [CrossRef] [PubMed]

110. Cook, M.T.; Tzortzis, G.; Charalampopoulos, D.; Khutoryanskiy, V.V. Production and Evaluation of Dry Alginate-Chitosan Microcapsules as an Enteric Delivery Vehicle for Probiotic Bacteria. Biomacromolecules 2011, 12, 2834-2840. [CrossRef] [PubMed]

111. Broaders, K.E.; Pastine, S.J.; Grandhe, S.; Fréchet, J.M.J. Acid-degradable solid-walled microcapsules for pH-responsive burst-release drug delivery. Chem. Commun. 2011, 47, 665-667. [CrossRef] [PubMed]

112. Chen, L.; Subirade, M. Elaboration and Characterization of Soy/Zein Protein Microspheres for Controlled Nutraceutical Delivery. Biomacromolecules 2009, 10, 3327-3334. [CrossRef] [PubMed]

113. Chun, H.; Kim, C.-H.; Cho, Y.-H. Microencapsulation of Lactobacillus plantarum DKL 109 using External Ionic Gelation Method. Korean J. Food Sci. Anim. Resour. 2014, 34, 692-699. [CrossRef] [PubMed]

114. Tomaro-Duchesneau, C.; Saha, S.; Malhotra, M.; Coussa-Charley, M.; Kahouli, I.; Jones, M.L.; Labbé, A.; Prakash, S. Probiotic Ferulic Acid Esterase Active Lactobacillus fermentum NCIMB 5221 APA Microcapsules for Oral Delivery: Preparation and in Vitro Characterization. Pharmaceuticals 2012, 5, 236-248. [CrossRef] [PubMed]

115. Caruso, F. (Ed.) Colloids and Colloid Assemblies; Wiley-VCH Verlag GmbH \& Co. KGaA: Weinheim, Germany, 2003.

116. Venkatesan, P.; Manavalan, R.; Valliappan, K. Microencapsulateation: A Vital Technique in Novel Drug Delivery System. J. Pharm. Sci. Res. 2009, 1, 26-35.

117. Singh, M.N.; Hemant, K.S.Y.; Ram, M.; Shivakumar, H.G. Microencapsulation: A promising technique for controlled drug delivery. Res. Pharm. Sci. 2010, 5, 65-77. [PubMed]

118. Tsuji, K. Microencapsulation of pesticides and their improved handling safety. J. Microencapsul. 2001, 18, 137-147. [CrossRef] [PubMed]

119. Green, D.W.; Mann, S.; Oreffo, R.O.C. Mineralized polysaccharide capsules as biomimetic microenvironments for cell, gene and growth factor delivery in tissue engineering. Soft Matter 2006, 2, 732-737. [CrossRef]

120. Kurosaki, T.; Kitahara, T.; Fumoto, S.; Nishida, K.; Yamamoto, K.; Nakagawa, H. Chondroitin Sulfate Capsule System for Efficient and Secure Gene Delivery. J. Pharm. Pharm. Sci. 2010, 13, 351-361. [CrossRef] [PubMed]

121. Desai, K.G.H.; Jin Park, H. Recent Developments in Microencapsulation of Food Ingredients. Dry. Technol. 2005, 23, 1361-1394. [CrossRef]

122. Herzfeldt, C.D.; Kümmel, R. Dissociation constants, solubilities and dissolution rates of some selected nonsteroidal antiinflammatories. Drug Dev. Ind. Pharm. 1983, 9, 767-793. [CrossRef]

123. Vayssières, L.; Chanéac, C.; Tronc, E.; Jolivet, J.P. Size Tailoring of Magnetite Particles Formed by Aqueous Precipitation: An Example of Thermodynamic Stability of Nanometric Oxide Particles. J. Colloid Interface Sci. 1998, 205, 205-212. [CrossRef] [PubMed]

124. Yiamsawas, D.; Baier, G.; Thines, E.; Landfester, K.; Wurm, F.R. Biodegradable lignin nanocontainers. RSC Adv. 2014, 4, 11661-11663. [CrossRef]

125. Tortora, M.; Cavalieri, F.; Mosesso, P.; Ciaffardini, F.; Melone, F.; Crestini, C. Ultrasound Driven Assembly of Lignin into Microcapsules for Storage and Delivery of Hydrophobic Molecules. Biomacromolecules 2014, 15, 1634-1643. [CrossRef] [PubMed]

126. Chen, N.; Dempere, L.A.; Tong, Z. Synthesis of pH-Responsive Lignin-Based Nanocapsules for Controlled Release of Hydrophobic Molecules. ACS Sustain. Chem. Eng. 2016, 4, 5204-5211. [CrossRef]

127. Chen, C.-K.; Wang, Q.; Jones, C.H.; Yu, Y.; Zhang, H.; Law, W.-C.; Lai, C.K.; Zeng, Q.; Prasad, P.N.; Pfeifer, B.A.; et al. Synthesis of pH-Responsive Chitosan Nanocapsules for the Controlled Delivery of Doxorubicin. Langmuir 2014, 30, 4111-4119. [CrossRef] [PubMed]

128. Zou, J.; Zhang, F.; Zhang, S.; Pollack, S.F.; Elsabahy, M.; Fan, J.; Wooley, K.L. Poly(ethylene oxide)-block-Polyphosphoester-graft-Paclitaxel Conjugates with Acid-Labile Linkages as a pH-Sensitive and Functional Nanoscopic Platform for Paclitaxel Delivery. Adv. Healthc. Mater. 2014, 3, 441-448. [CrossRef] [PubMed]

129. Mina, M.V.; Puzyk, I.P.; Puzyk, M.V. The effect of acids on fluorescence of coumarin-6 in organic solvents. Opt. Spectrosc. 2013, 114, 244-246. [CrossRef]

130. Nghi, D.H.; Bittner, B.; Kellner, H.; Jehmlich, N.; Ullrich, R.; Pecyna, M.J.; Nousiainen, P.; Sipila, J.; Huong, L.M.; Hofrichter, M.; et al. The Wood Rot Ascomycete Xylaria polymorpha Produces a Novel GH78 Glycoside Hydrolase That Exhibits $\alpha$-L-Rhamnosidase and Feruloyl Esterase Activities and Releases 
Hydroxycinnamic Acids from Lignocelluloses. Appl. Environ. Microbiol. 2012, 78, 4893-4901. [CrossRef] [PubMed]

131. Dowding, P.J.; Atkin, R.; Vincent, B.; Bouillot, P. Oil Core-Polymer Shell Microcapsules Prepared by Internal Phase Separation from Emulsion Droplets. I. Characterization and Release Rates for Microcapsules with Polystyrene Shells. Langmuir 2004, 20, 11374-11379. [CrossRef] [PubMed]

132. Ten, E.; Ling, C.; Wang, Y.; Srivastava, A.; Dempere, L.A.; Vermerris, W. Lignin Nanotubes As Vehicles for Gene Delivery into Human Cells. Biomacromolecules 2014, 15, 327-338. [CrossRef] [PubMed]

133. Magrez, A.; Kasas, S.; Salicio, V.; Pasquier, N.; Seo, J.W.; Celio, M.; Catsicas, S.; Schwaller, B.; Forró, L. Cellular Toxicity of Carbon-Based Nanomaterials. Nano Lett. 2006, 6, 1121-1125. [CrossRef] [PubMed]

134. Liu, Y.; Zhao, Y.; Sun, B.; Chen, C. Understanding the Toxicity of Carbon Nanotubes. Acc. Chem. Res. 2013, 46, 702-713. [CrossRef] [PubMed]

135. Zhong, X.; Qian, Y.; Huang, J.; Yang, D.; Deng, Y.; Qiu, X. Fabrication of Lignosulfonate Vesicular Reverse Micelles to Immobilize Horseradish Peroxidase. Ind. Eng. Chem. Res. 2016, 55, 2731-2737. [CrossRef]

136. Wang, X.; Zhao, J. Encapsulation of the Herbicide Picloram by Using Polyelectrolyte Biopolymers as Layer-by-Layer Materials. J. Agric. Food Chem. 2013, 61, 3789-3796. [CrossRef] [PubMed]

137. Figueiredo, P.; Lintinen, K.; Kiriazis, A.; Hynninen, V.; Liu, Z.; Bauleth-Ramos, T.; Rahikkala, A.; Correia, A.; Kohout, T.; Sarmento, B.; et al. In vitro evaluation of biodegradable lignin-based nanoparticles for drug delivery and enhanced antiproliferation effect in cancer cells. Biomaterials 2017, 121, 97-108. [CrossRef] [PubMed]

138. Dai, L.; Liu, R.; Hu, L.Q.; Zou, Z.F.; Si, C.L. Lignin Nanoparticle as a Novel Green Carrier for the Efficient Delivery of Resveratrol. ACS Sustain. Chem. Eng. 2017, 5, 8241-8249. [CrossRef]

(C) 2017 by the authors. Licensee MDPI, Basel, Switzerland. This article is an open access article distributed under the terms and conditions of the Creative Commons Attribution (CC BY) license (http:/ / creativecommons.org/licenses/by/4.0/). 